\title{
Thermal modeling and experimental evaluation of five different photovoltaic modules integrated on prototype test cells with and without water flow
}

\author{
Vivek Tomar \\ Indian Institute of Technology Delhi, vivektomariitd@gmail.com
}

G.N. Tiwari

Indian Institute of Technology Delhi

T.S. Bhatti

Indian Institute of Technology, Delhi

See next page for additional authors

Follow this and additional works at: https://arrow.tudublin.ie/dubenart

Part of the Environmental Sciences Commons

\section{Recommended Citation j.enconman.2018.03.039. \\ This Article is brought to you for free and open access by the Dublin Energy Lab at ARROW@TU Dublin. It has been accepted for inclusion in Articles by an authorized administrator of ARROW@TU Dublin. For more information, please contact arrow.admin@tudublin.ie, aisling.coyne@tudublin.ie,gerard.connolly@tudublin.ie.}

Vivek Tomar, G.N. Tiwari, T.S. Bhatti, Brian Norton, Thermal modeling and experimental evaluation of five different photovoltaic modules integrated on prototype test cells with and without water flow, Energy Conversion and Management, Volume 165, 2018, Pages 219-235, ISSN 0196-8904, DOI: 10.1016/

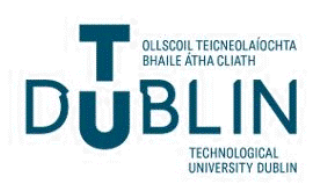




\section{Authors}

Vivek Tomar, G.N. Tiwari, T.S. Bhatti, and Brian Norton

This article is available at ARROW@TU Dublin: https://arrow.tudublin.ie/dubenart/77 


\title{
Thermal modeling and experimental evaluation of five different photovoltaic modules integrated on prototype test cells with and without water flow
}

\author{
Vivek Tomar $^{\mathrm{a}, *}$, G.N. Tiwari ${ }^{\mathrm{a}}$, T.S. Bhatti ${ }^{\mathrm{a}}$, Brian Norton $^{\mathrm{b}}$

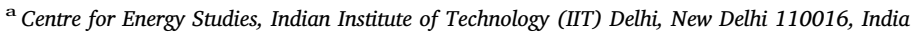 \\ ${ }^{\mathbf{b}}$ Dublin Energy Lab, Dublin Institute of Technology (DIT), Dublin 7, Ireland
}

\section{A R T I C L E I N F O}

\section{Keywords:}

Photovoltaic-thermal modules

Mono and polycrystalline PV modules

Thin film PV modules

Test cell

Mass flow rate

Thermal modelling

\begin{abstract}
A B S T R A C T
An analytical model of temperature dependent electrical and thermal efficiency of mono-crystalline (m-Si), polycrystalline (p-Si), amorphous silicon thin film (a-Si), cadmium telluride thin film (CdTe) and copper indium gallium selenide (CIGS) photovoltaic modules integrated on five prototypes identical insulted test cells is developed with and without surface water flow. This model helps in ascertaining the influence of temperature on their performance of building integrated photovoltaic-thermal (BiPVT) system. The theoretically calculated results are experimentally validated in outdoor ambient environment. The electrical \& thermal efficiencies are calculated for both high and low mass flow rate of water, $\dot{m}_{w}$. Daily average electrical efficiency of photovoltaic modules; m-Si, p-Si, a-Si, CdTe and CIGS with and without water flow are found to be $12.30 \%, 10.98 \%, 6.08 \%$, $6.60 \%$ and $7.71 \%$, and $11.41 \%, 10.30 \%, 5.86 \%, 6.26 \%$ and $6.99 \%$ respectively. In constant room temperature mode, variation in mass flow rate of water, $\dot{m}_{w}$ is also evaluated. Overall thermal efficiency and overall exergy for all photovoltaic modules in both cases are also calculated. The characteristic equations of photovoltaic modules integrated on test cells are also developed for both cases.
\end{abstract}

\section{Introduction}

Photovoltaic cell is an energy conversion device and it has a threshold solar irradiance (photon energy) corresponding to energy gap beyond which no electron-hole pair generate instead dissipate their energy in heat forms $[1,2]$. Photovoltaic cell has the capability to convert about $6-19 \%$ of incoming solar irradiance into electricity depending upon types of photovoltaic cell technology and operating conditions. Almost more than $50 \%$ of incident solar irradiance goes waste and is converted into heat that leads to rise in photovoltaic cell operating temperature of about $50{ }^{\circ} \mathrm{C}$ above ambient temperature $[3,4]$. Hence, the electrical yields drop (decrease in electrical efficiencies) and permanent structural damage due long duration thermal stress are some undesirable consequences faced by photovoltaic modules [5]. The use of coolant as a fluid stream like air/water helps in cooling down photovoltaic module, it enhances electrical output and with proper design to reuse the extracted heat by coolant are the basic incentives towards advance in photovoltaic-thermal hybrid technology [6]. Here, both natural and forced circulation helps in reducing operating temperature of photovoltaic module and the simultaneous cooling of the photovoltaic module attains acceptable electrical efficiency coupled with heat extraction devices to achieve increased overall efficiency [7-10]. Since the photovoltaic-thermal concept was introduced, several researchers have conducted experimentation and numerical calculation aiming higher overall energy efficiency [11,12]. Some significant characteristics of photovoltaic-thermal system include dual nature like electricity and thermal output, flexibility towards using as a Building integrated photovoltaic-thermal (BiPVT) application, and use of heat output in both heating and cooling (desiccant cooling) suitable for domestic application [13-15]. Initially, the glazed collector using both air and liquid type fluid got considerable attention followed by an unglazed photovoltaic collector coupled with a heat pump getting significant focus $[16,17]$. Photovoltaic-thermal water and air based systems are most commonly used that employ water and air as a working fluid respectively, wherein, former being more efficient due to high heat conductivity/capacity $[18,19,8,20-25]$. However, water based system required some extensive modification to enable water tight and corrosion free structure, whereas, in natural or forced mode in air based photovoltaic-thermal through air channel on rear, top or both surfaces of photovoltaic is a simplest way to extract heat $[26,27]$. As far as heat extraction process is concerned, the efficacy of photovoltaic-thermal systems depends upon the type of photovoltaic technology used. Mono-

\footnotetext{
* Corresponding author.

E-mail address: vivektomariitd@gmail.com (V. Tomar).
} 


\begin{tabular}{|c|c|c|c|}
\hline \multicolumn{3}{|c|}{ Nomenclature } & \multirow{2}{*}{$\begin{array}{l}\left.\mathrm{T}_{\mathrm{o}}=25^{\circ} \mathrm{C}\right)(\mathrm{V}) \\
\text { module voltage at MPP }(\mathrm{V}) \\
\text { power generate by module }(\mathrm{W})\end{array}$} \\
\hline$a$ & aperture area of water opening through the tube $\left(\mathrm{m}^{2}\right)$ & $P_{m}$ & \\
\hline$A_{m}$ & area of photovoltaic module $\left(\mathrm{m}^{2}\right)$ & $P_{m, o}$ & power generate by module at STC $\left(\mathrm{I}(\mathrm{t})=1000 \mathrm{~W} / \mathrm{m}^{2}\right.$ and \\
\hline$A_{t}$ & area of inside wall surface of test cell $\left(\mathrm{m}^{2}\right)$ & & $\left.\mathrm{T}_{\mathrm{o}}=25^{\circ} \mathrm{C}\right)(\mathrm{W})$ \\
\hline$A R C$ & alternating reference condition & $v, V$ & air velocity (m/s)(front and back surface) \\
\hline$B$ & breadth of photovoltaic module (m) & $\vartheta_{w}$ & velocity of water $(\mathrm{m} / \mathrm{s})$ \\
\hline C & specific heat $(\mathrm{J} / \mathrm{kg} \mathrm{K})$ & $\nu$ & kinematic viscosity of water \\
\hline$F_{R}$ & heat removal factor, dimensionless & & \\
\hline$h$ & heat transfer coefficient $\left(\mathrm{W} / \mathrm{m}^{2} \mathrm{~K}\right)$ & \multicolumn{2}{|c|}{ Subscripts } \\
\hline FF & fill factor, dimensionless & & \\
\hline$h_{t w}$ & heat transfer coefficient from water to ambient $\left(\mathrm{W} / \mathrm{m}^{2}{ }^{\circ} \mathrm{C}\right)$ & $1 / 2$ & case $1 / 2$ \\
\hline$h_{e w}$ & $\begin{array}{l}\text { evaporative heat transfer coefficient from water to am- } \\
\text { bient }\left(\mathrm{W} / \mathrm{m}^{2} \mathrm{~K}\right)\end{array}$ & $\begin{array}{l}a \\
\operatorname{arc}\end{array}$ & $\begin{array}{l}\text { ambient, air } \\
\text { anti-reflective coating }\end{array}$ \\
\hline$h_{c w}$ & $\begin{array}{l}\text { convective heat transfer coefficient from water to ambient } \\
\left(\mathrm{W} / \mathrm{m}^{2} \mathrm{~K}\right)\end{array}$ & $\begin{array}{l}A R C \\
b\end{array}$ & $\begin{array}{l}\text { alternative reference condition } \\
\text { tedlar polymer layer }\end{array}$ \\
\hline$h_{r w}$ & $\begin{array}{l}\text { radiative heat transfer coefficient from water to ambient } \\
\left(\mathrm{W} / \mathrm{m}^{2} \mathrm{~K}\right)\end{array}$ & $\begin{array}{l}e c \\
\text { th }\end{array}$ & $\begin{array}{l}\text { ethyl vinyl acetate (EVA) layer } \\
\text { thermal }\end{array}$ \\
\hline$I(t)$ & incident solar intensity $\left(\mathrm{W} / \mathrm{m}^{2}\right)$ & $i$ & inlet, insulation fitted in test cell \\
\hline$k$ & thermal conductivity (W/m K) & over,ex & overall exergy \\
\hline$l$ & thickness (m) & over, th & overall thermal \\
\hline$L$ & length of photovoltaic module (m) & $m$ & module \\
\hline$\dot{m}_{w}$ & mass flow rate of water $(\mathrm{kg} / \mathrm{s})$ & $r$ & test cell room \\
\hline$M_{r}$ & mass of air inside test cell $(\mathrm{kg})$ & $e$ & effective \\
\hline$\dot{Q}_{u}$ & rate of useful thermal energy (W) & $g$ & glass \\
\hline$t$ & time (hr) & $G i$ & glass covering \\
\hline$T$ & temperature $\left({ }^{\circ} \mathrm{C}\right)$ & $P V$ & photovoltaic module \\
\hline$U_{L}$ & overall heat transfer coefficient $\left(\left(\mathrm{W} / \mathrm{m}^{2} \mathrm{~K}\right)\right)$ & $r m$ & rear metal contact \\
\hline$U_{m a}$ & $\begin{array}{l}\text { an overall heat transfer coefficient from module to am- } \\
\text { bient through glass cover }\left(\mathrm{W} / \mathrm{m}^{2} \mathrm{~K}\right)\end{array}$ & $w$ & water, wood \\
\hline$U_{m r}$ & $\begin{array}{l}\text { an overall heat transfer coefficient from water/module to } \\
\text { inside of test cell }\left(\mathrm{W} / \mathrm{m}^{2} \mathrm{~K}\right)\end{array}$ & Greek syn & abols \\
\hline$U_{t}$ & $\begin{array}{l}\text { an overall heat transfer coefficient from inside of test cell } \\
\text { to ambient }\left(\mathrm{W} / \mathrm{m}^{2} \mathrm{~K}\right)\end{array}$ & $\begin{array}{l}\alpha_{c} \\
\alpha_{\tau}\end{array}$ & $\begin{array}{l}\text { absorptivity of photovoltaic modules/cells } \\
\text { transmittivity of modules }\end{array}$ \\
\hline$U_{m w}$ & $\begin{array}{l}\text { an overall heat transfer coefficient from module to water } \\
\text { through glass cover }\left(\mathrm{W} / \mathrm{m}^{2} \mathrm{~K}\right)\end{array}$ & $\begin{array}{l}\alpha \tau_{e} \\
\beta_{c}\end{array}$ & $\begin{array}{l}\text { product of effective absorptivity and transmittivity } \\
\text { packing factor of solar cell in photovoltaic modules }\end{array}$ \\
\hline$R_{e}$ & reflectivity & $\beta_{o}$ & temperature coefficient of electrical efficiency $\left(\% / \mathrm{K}^{-1}\right)$ \\
\hline$R_{e l}$ & Reynolds number & $\eta$ & efficiency (percentage) \\
\hline $\begin{array}{l}P_{r} \\
P\end{array}$ & $\begin{array}{l}\text { Prandtl number } \\
\text { pressure (pascal) }\end{array}$ & $\eta_{m o}$ & $\begin{array}{l}\text { efficiency at standard test condition }\left(\mathrm{I}(\mathrm{t})=1000 \mathrm{~W} / \mathrm{m}^{2}\right. \\
\text { and } \mathrm{T}_{\mathrm{o}}=25^{\circ} \mathrm{C} \text { ) (percentage) }\end{array}$ \\
\hline$I_{s c}$ & short circuit current (A) & $\eta_{m}$ & temperature dependent efficiency (percentage) \\
\hline & $\begin{array}{l}\text { short circuit current at STC }\left(\mathrm{I}(\mathrm{t})=1000 \mathrm{~W} / \mathrm{m}^{2} \text { and }\right. \\
\mathrm{T}_{\mathrm{o}}=25^{\circ} \mathrm{C} \text { ) (A) }\end{array}$ & $\begin{array}{l}\eta_{\text {th }} \\
\eta_{\text {over,th }}\end{array}$ & $\begin{array}{l}\text { instantaneous thermal efficiency (percentage) } \\
\text { overall thermal efficiency (percentage) }\end{array}$ \\
\hline$I_{m p}$ & module current at MPP (A) & $\eta_{\text {over, ex }}$ & overall exergy efficiency (percentage) \\
\hline$V_{o c}$ & open circuit voltage $(\mathrm{V})$ & $\omega$ & temperature dependent coefficient $(\% / \mathrm{K})$ \\
\hline$V_{o c}$ & open circuit voltage at STC $\left(\mathrm{I}(\mathrm{t})=1000 \mathrm{~W} / \mathrm{m}^{2}\right.$ and & & \\
\hline
\end{tabular}

crystalline silicon (m-Si), poly crystalline silicon (p-Si) and in advanced thin technology, amorphous silicon thin film (a-Si), cadmium telluride (CdTe) and copper iridium gallium selenide (CIGS) are market available technologies. Among these $\mathrm{m}$-Si still possess largest market share due to its high efficiency though slow energy intensive manufacturing process make it a expensive option [28-30]. Numerous approaches have been taken to reduce the cost of mono-crystalline photovoltaic cell, while the development of poly-crystalline photovoltaic cell has given a new dimension and substantial push towards crystalline based photovoltaic technologies. Among advanced thin film technology, a-Si has attained a significant market share due to low manufacturing cost and being cost effective for low temperatures application. CdTe and CIGS show potential in future aspects, still several research groups are consistently working with aim to increase efficacy and achieve low capital intensive manufacturing process [31-35]. From aesthetic point of view, both CdTe and CIGS are considered as more desirable options due its ductility and wall mounting susceptibility. Photovoltaic modules or panels usually contain six layers; covering glass, Anti-reflecting coating (ARC), solar cell or thin film, Ethylene Vinyl Acetate (EVA) layer, metal sheet as back cover and tedlar layer. The tempered glass is used as a covering glass that has gone through rapid heating and cooling to improve its quality, and has high transmittance. ARC is typically of nanometer thickness for providing feasible path to incident photons into solar cell. Some photovoltaic modules use wafer or film depending upon the technology used in manufacturing process. Ethylene Vinyl Acetate (EVA)/ Polyvinyl Butyral (PVB) is used in encapsulation of solar cell with a covering glass. In rear side of solar cell/thin film, metal contact (gold/silver/aluminium) is used by screen printing process. Some photovoltaic modules such as mono crystalline, polycrystalline silicon use polyvinyl fluoride as a tedlar for additional insulation whereas all other technologies based, and especially thin film use tempered black glass. Due to thick lamination, CIGS does not use back cover [13,30-35].

This reviewing summary suggested that a considerable amount of 
research study focused either on simulation of the whole system using software tools or in the development of panel itself. There is a lack of study focusing on the monitoring of the photovoltaic thermal system in ambient condition and considering viability in implementation perspective. So far several models have been developed but none of researchers has validated the model experimentally.

The aim of this study is to understand the thermal performance of building integrated photovoltaic-thermal (BiPVT) system for which five different photovoltaic modules; mono-crystalline silicon (m-Si), polycrystalline (p-Si), amorphous thin film (a-Si), cadmium telluride thin film (CdTe) and copper gallium indium de-selenide (CIGS), were integrated on five prototype insulated test cells. During experimentation, a thin layer of water is also allowed to flow over the top surface of photovoltaic modules to comprehend the effect of cooling on the performance of these photovoltaic modules. An analytical theoretical model is developed for electrical efficiency of five different photovoltaic modules with and without water flow on it. The proposed model includes the mathematical expression of electrical efficiency, operating temperature of module and test inside (room) air temperature considering design parameters of integrated building. The theoretically calculated results are validated with the experimental observations for all photovoltaic modules. The variable mass flow rate of water to achieve constant room temperature mode is also carried out. The overall thermal efficiency and exergy analysis is executed for each module.

This research is carried out to verify that the real behaviour of five different photovoltaic technology as building integrated photovoltaic thermal system is equivalent to proposed analytical model and therefore to generalise their behaviour in other building implementation prospects. Having a model able to predict the performance of different photovoltaic technology based PVT system constitutes a huge advantage for the architects, energy analyst. Once the desired expression is achieved, viability of different photovoltaic technology for implementation perspective can be analyzed by substituting known design parameters and ambient condition.

\section{Problem identification \& working principle}

In the present analysis, five different photovoltaic modules namely; mono-crystalline silicon (m-Si), polycrystalline silicon (p-Si), amorphous thin film silicon (a-Si), cadmium telluride (CdTe) and copper iridium gallium selenide (CIGS) are used. Each of the modules is mounted on five identical complete insulated test cells with latitude angle facing south as shown in Fig. 1. The experimental system was situated at the roof of IIT Delhi building, New Delhi. As New Delhi is situated at $28^{\circ} 36^{\prime} 50^{\prime \prime} \mathrm{N} 77^{\circ} 12^{\prime} 32^{\prime \prime} \mathrm{E}$, the five identical prototype test cells were designed in such a way that integrated PV modules were south oriented inclined at latitude angle to the horizontal, and the schematic view of a single identical test cell and its measurement/ configuration is shown in Fig. 2. The prototype test cells are made up of wooden board, and polystyrene sheet of thickness $(0.12 \mathrm{~m})$ was uniformly diffused inside test cells to maintain insulation. The main characteristic values of photovoltaic modules, different electrical efficiency under standard test condition (STC) (Solar intensity, 1000 W/ $\mathrm{m}^{2}$, module temperature, $25^{\circ} \mathrm{C}$ ) and temperature coefficient of electrical efficiency are tabulated in Table 1 . This prototype based physical experiment reflects building integrated photovoltaic-thermal systems. This study underscores the feasibility of photovoltaic technology at distributed levels that not only consider electrical load but also incorporate thermal performance in form of space and water heating. Important consideration of the experiment was that no air-exchange from ambient to inside of test cell was allowed, and thermal energy available in form of test cell room temperature, $T_{r}$ rise attributes to heat transfer through different kind of PV modules. Introducing the concept of surface flow water cooling of five different PV technologies gives this study a new pace in both electrical and thermal view by electrical efficiency improvement and surface water flow temperature rise and further provides cleaning in case of sufficient water resources with caution to avoid delamination. Surface water flow has two functions, to reduce the operating temperature of photovoltaic modules and to reduce upper heat losses with rising temperature of surface water. Further the thermal resistance and thermal energy diagram for both with and without surface water flow over photovoltaic modules integrated over prototype tests are shown in Fig. 3. Moreover, the controlled mass flow rate of water to attain constant room temperature mode was also achieved, and we developed the formulae for mass flow rate for constant room temperature $\left(\mathrm{T}_{\mathrm{r}}=25^{\circ} \mathrm{C}\right)$ mode application. This study is limited to thermal aspects of overall system and does not take into account the economical view. It is opined that if the surface water flow is considered for photovoltaic array instead of single photovoltaic module then economical consideration needed to be discussed. The economical analysis is always required because such PV panels are mounted in various locations since there is more than a single one.

For building implementation perspective, the photovoltaic modules

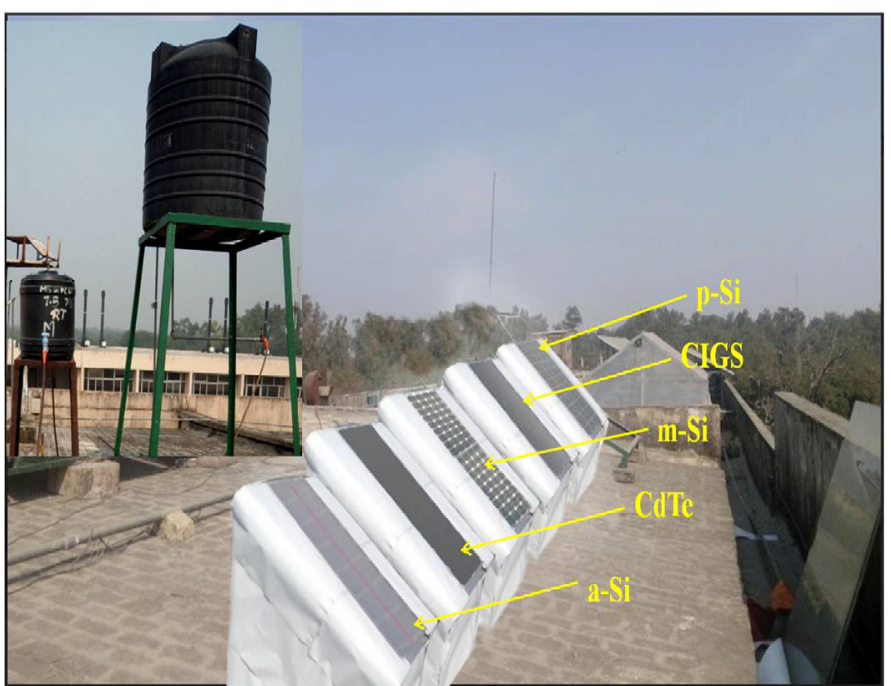

(a)

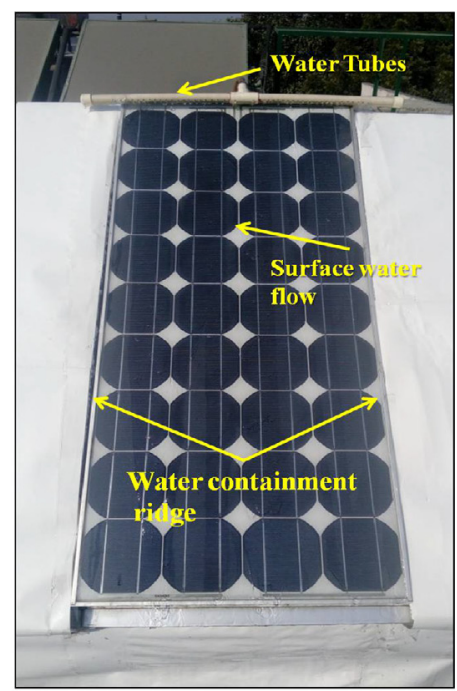

(b)

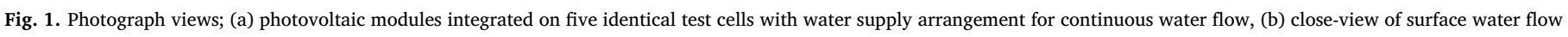
on module. 


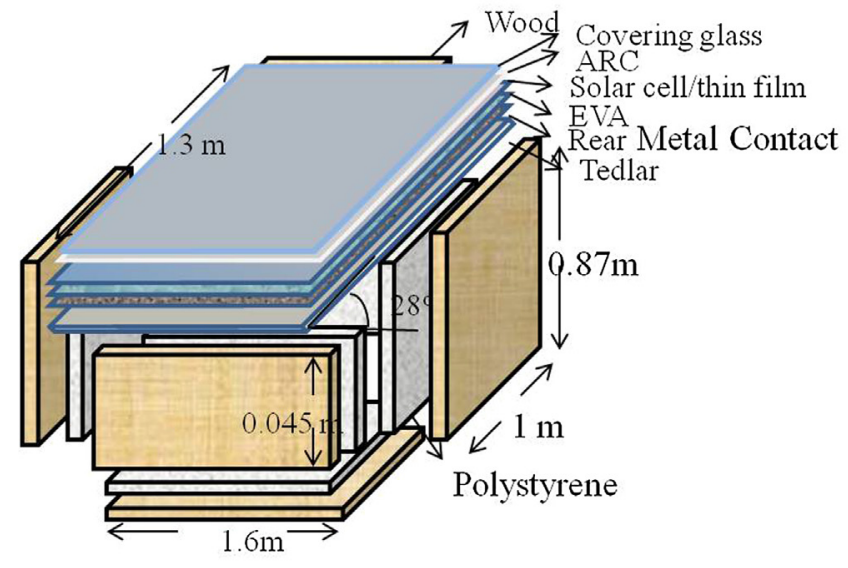

(a)

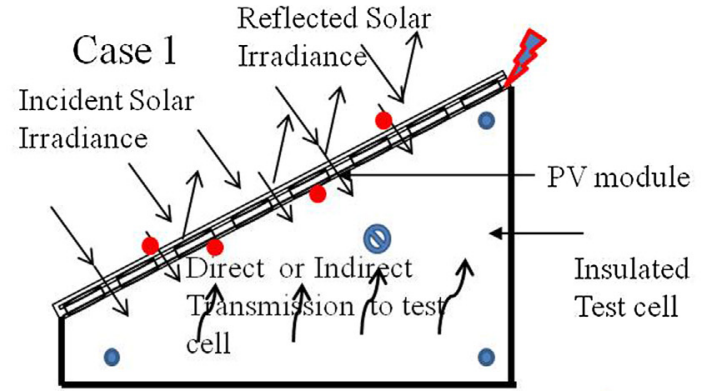

(1)

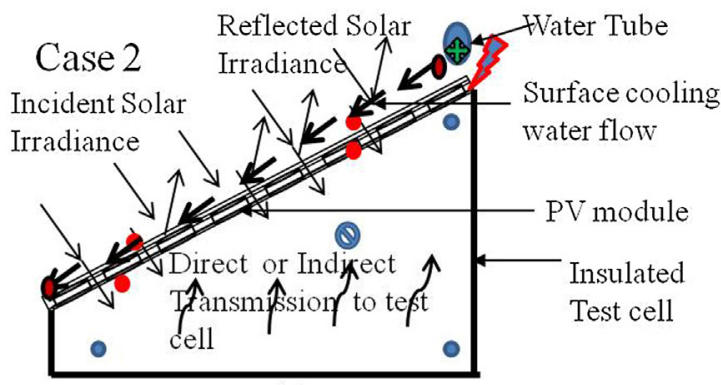

(b)

Measuring points: - module operating temperature, $T_{c}, \quad$ top/bottom fluid water temperature $T_{w, x=0} / T_{w, x=L}$,

- test cell inside air temperature, $\mathrm{T}_{\mathrm{r}}$, electrical measuring by multimeter point, $\mathrm{I}_{\mathrm{sc}} / \mathrm{V}_{\mathrm{oc}}$, Installed

thermometer for $\mathrm{T}_{\mathrm{a}} / \mathrm{T}_{\mathrm{r}}$, mass flow rate of air, $\mathrm{m}_{\mathrm{a}}$.

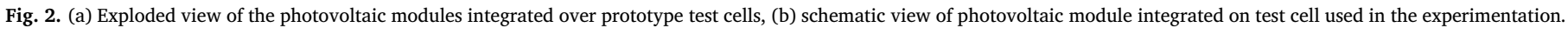

Table 1

Characteristic values of different photovoltaic modules.

\begin{tabular}{|c|c|c|c|c|c|c|c|c|}
\hline Modules/specification & $\begin{array}{l}\mathrm{P}_{\max } \\
\mathrm{W}_{\mathrm{p}}\end{array}$ & $\begin{array}{l}\mathrm{V}_{\mathrm{mp}} \\
\text { Volt }\end{array}$ & $\begin{array}{l}\mathrm{I}_{\mathrm{mp}} \\
\text { Amp. }\end{array}$ & $\begin{array}{l}\mathrm{V}_{\mathrm{oc}, \mathrm{o}} \\
\text { Volt }\end{array}$ & $\begin{array}{l}\mathrm{I}_{\mathrm{sc}, \mathrm{o}} \\
\text { Amp. }\end{array}$ & $\begin{array}{l}\eta_{\mathrm{mo}} \\
\%\end{array}$ & $\begin{array}{l}\beta_{\mathrm{o}} \\
\% / \mathrm{K}\end{array}$ & References \\
\hline $\mathrm{m}-\mathrm{Si}$ & 75 & 17.7 & 4.2 & 21.4 & 4.6 & 13.5 & 0.45 & Vats et al. [13]; Makrides et al. [36]; Virtuani et al. [37] \\
\hline $\mathrm{p}-\mathrm{Si}$ & 75 & 17.6 & 4.32 & 21.8 & 4.7 & 11.6 & 0.4 & Vats et al. [13] Makrides et al. [36]; Virtuani et al. [37] \\
\hline $\mathrm{a}-\mathrm{Si}$ & 90 & 100 & 0.9 & 136 & 1.14 & 6.3 & 0.2 & Vats et al. [13]; Makrides et al. [36]; Virtuani et al.[37] \\
\hline CdTe & 90 & 47.4 & 1.94 & 60.5 & 2.11 & 6.9 & 0.26 & Vats et al. [13]; Makrides et al. [36]; Virtuani et al. [37] \\
\hline CIGS & 90 & 72.9 & 1.23 & 91.9 & 1.36 & 8.2 & 0.4 & Vats et al. [13]; Makrides et al. [36]; Virtuani et al. [37] \\
\hline
\end{tabular}

are integrated on fixed mounted structure. Therefore, to understand the efficacy of photovoltaic thermal system in utilizing incident solar irradiance through-out the year for overall performance, Soulayman and Hammound [36], Ahmad and Tiwari [37] and Altarawneh et al. [38] have computed optimal tilt angle including experimental location, New Delhi for fixed structure with different inclination angle, and proposed the maximum overall performance on facing south with tilt angle equal to the latitude of the location.

Infrared digital thermometer (Extech, range: $-50{ }^{\circ} \mathrm{C}$ to $1000{ }^{\circ} \mathrm{C}$, least count 0.1 ) along with 10-channel digital temperature indicator (In SQU, range: $-20^{\circ} \mathrm{C}$ to $450{ }^{\circ} \mathrm{C}$, resolution $0.1{ }^{\circ} \mathrm{C}$ ) with calibrated T-type thermocouple (range: -200 to $350^{\circ} \mathrm{C}$, least count 0.1 ) was used to measure the module operating temperature, $\mathrm{T}_{\mathrm{m}}$ and flowing water temperature at both upper and lower side of photovoltaic modules. Here, T-type thermocouples were simply attached using thermal conducting adhesive on the front and rear surface of each module at five different locations on both sides, and there average value is considered for modules operating temperature, $\mathrm{T}_{\mathrm{m}}$. For measuring water temperature, calibrated T-type thermocouples were fitted just above the photovoltaic modules without contacting the surface so that only flowing water makes a contact with the thermocouples. Before observation, thermocouples were in thermal equilibrium though no equilibrium is needed for infrared thermometer due to its instant measuring capacity. Mercury thermometers (Range: $0-120^{\circ} \mathrm{C}$, least count: $0.2^{\circ} \mathrm{C}$ ) and calibrated T-type thermocouples were used to measure the test cell inside room temperature, $T_{r}$ and ambient temperature, $T_{a}$. A mercury thermometer was installed in shaded region of outside environment to measure $\mathrm{T}_{\mathrm{a}}$, and five thermometers were installed at the centre of each prototype test cells to measure $\mathrm{T}_{\mathrm{r}}$. Here, again the T-type thermocouples were instituted at different location and their average was considered for test cell inside room temperature, $\mathrm{T}_{\mathrm{r}}$. For measuring the incident solar irradiance, calibrated electronic digital solarimeter (CEL, range $0-1200 \mathrm{~W} / \mathrm{m}^{2}$, least count: $1 \mathrm{~W}$ ) was employed that has similar spectral response as investigating photovoltaic modules used. Each time during observation, digital solarimeter was kept adjacent to the modules with same plane of array. For measuring short circuit current, $\mathrm{I}_{\mathrm{sc}}$, open circuit voltage, $\mathrm{V}_{\mathrm{oc}}$, load current and load voltage, an AC/DC clamp meter/multi-meter (Fluke $87 \mathrm{~V}$ multi-meters, least count: $0.2 \%$ for current \& $0.06 \%$ for voltage) was employed for taking observation with varying loads $0-5 \mathrm{~K} \Omega$ connected with modules. An electronic digital anemometer (Lutron, AM-4201, range $0.2-30 \mathrm{~m} / \mathrm{s}$, least count: $0.1 \mathrm{~m} / \mathrm{s}$ ) was used to measure the air velocity.

\subsection{Uncertainty analysis}

In an uncontrolled outdoor condition, an uncertainty was introduced in junction temperature and backside temperature. Due to the considerable temperature spreads, inhomogeneity was introduced even after taking evaluation by infrared thermometer [38-42]. Similarly, uncertainty was introduced in air velocity measurement due to 


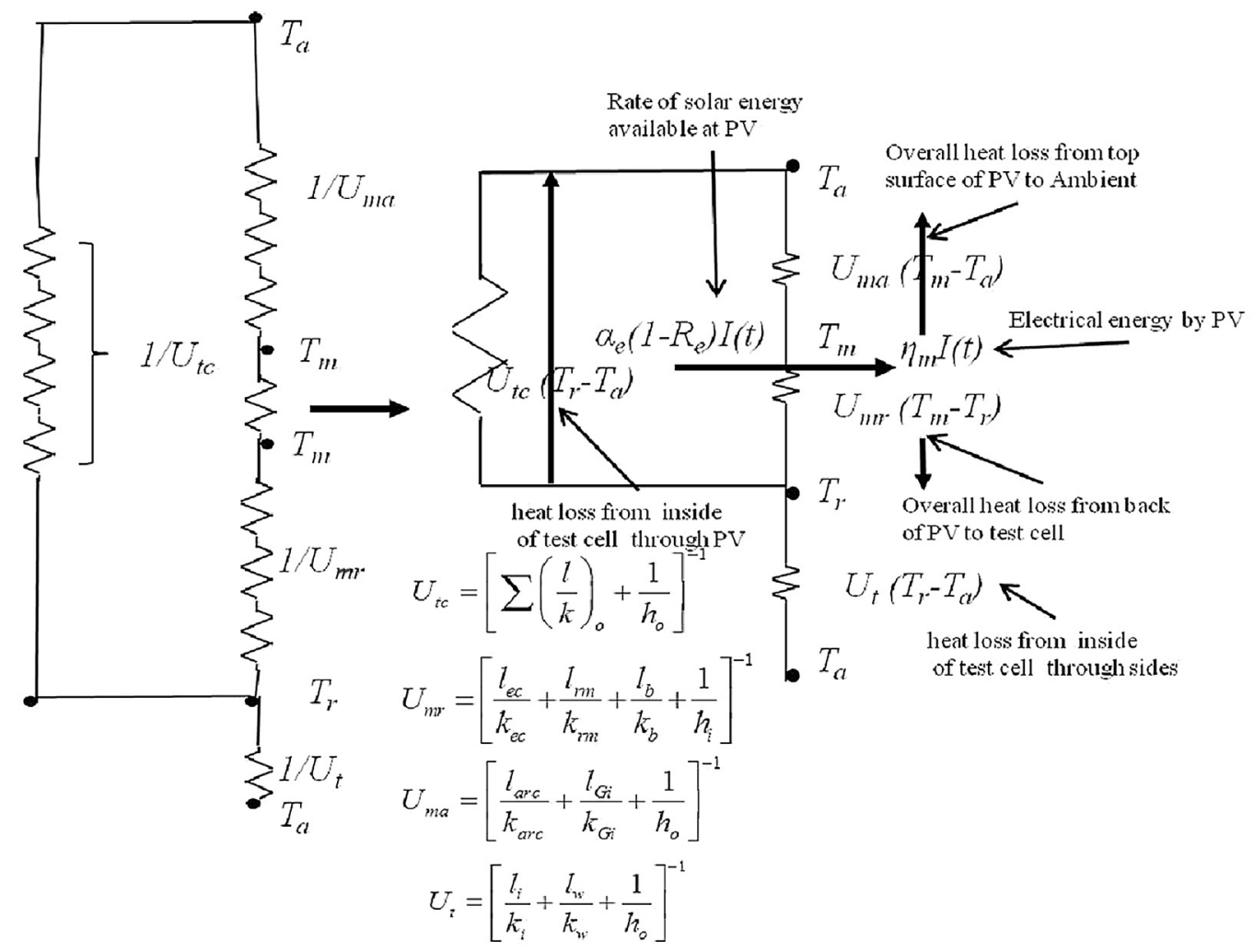

(a)

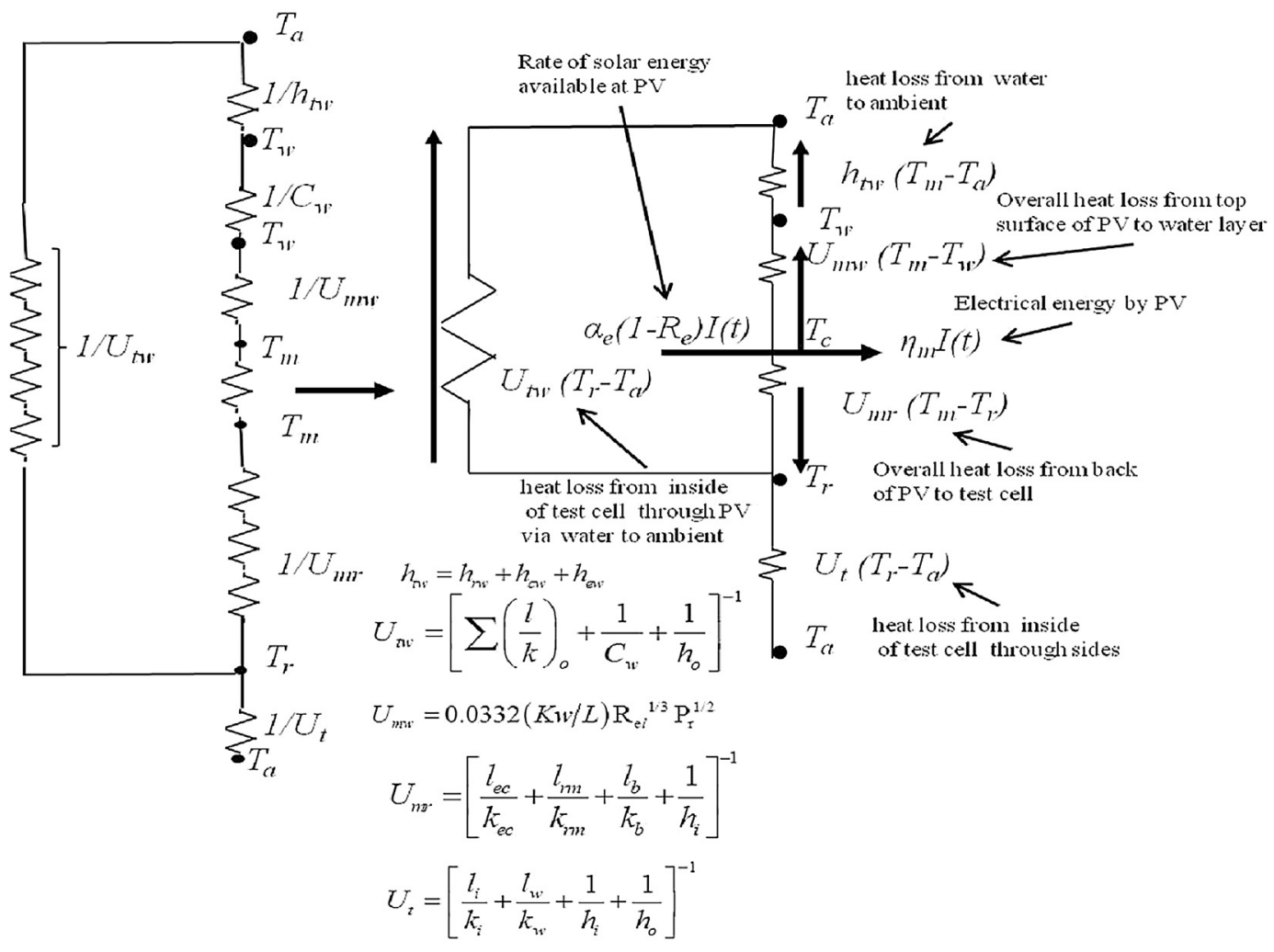

(b)

Fig. 3. Thermal resistance and the thermal energy circuit diagram for photovoltaic module integrated on prototype test cell; (a) without water flow, (b) with water flow. 
uncontrolled flow, also, illumination intensity also gets influenced due to abrupt behaviour of local weather condition that create detrimental effect on the thermal analysis of system. Therefore, the total uncertainty generated by measuring instrument in thermal analysis is shown in Table 2. Though, this analysis indicates that all uncertainties were in the expected range [43]. During experimentation in outdoor condition, STC of photovoltaic modules is almost impossible therefore correction has to be performed from real to standard condition directly after getting measurements from instrument used which is state of art or manually performed afterwards. The standard uncertainty corresponding to the uncertainty sources are combined after taking aggregating final expanded uncertainty according to their corresponding distribution ( $\mathrm{k}=2$ for normal and $\mathrm{k}=1.73$ for rectangular) [41-45]. Moreover, the standard uncertainty related threshold irradiance, nonuniformity in incident solar irradiance and temperature fluctuation is expressed in percentage error to reflect poor quality in current and voltage measurement. The uncertainty generated during the measurement of different parameters of photovoltaic modules; current, voltage and power are tabulated in Table 3. This uncertainty analysis is based on the method discussed by Müllejans et al. [42]. For current measurement, raw current measurement and irradiance measurement both contribute to current measurement [42]. Here, the standard uncertainty contribution of measured irradiance for current measurement was about $1.82-188 \%$ for normal distribution $(\mathrm{k}=2)$ whereas for voltage their contribution was about $0.11 \%$. On the other hand, ambient temperature as well as inhomogenity $(\mathrm{k}=1.73$, non-uniformity of temperature over photovoltaic modules) are two important considerations for voltage measurement, and their corresponding standard uncertainty was $0.04 \%$ and $0.23 \%$ respectively. Similarly, hysteresis loss, thermal conductivity uncertainly, aging effects are some error uncertainty that influenced the parametric values for all kind of photovoltaic technology $[42,45]$.

\section{Thermal modelling}

The electrical efficiencies of photovoltaic modules integrated on test cells with and without water thin film are calculated by using energy balance equations. Therefore, following assumptions have been made:

- Experimental systems are in quasi-steady state.

- Uniform surface temperature of photovoltaic modules.

- Water flow over the surface of photovoltaic modules as a film i.e. without water storage.

- Homogeneously configuration of insulating material inside test cells.

- Negligible thermal loss due to ventilation/infiltration from test cells.

Case 1: Photovoltaic module integrated on test cell without water flow For photovoltaic modules, the energy balance equation can be written as,
Table 3

Measurements of combined standard (Std.) and expanded (Exp.) uncertainties in percentage (\%) for estimated parameter of different PV modules [39,42].

\begin{tabular}{llllllllllll}
\hline Parameters & $\mathrm{m}-\mathrm{Si}$ & \multicolumn{3}{c}{$\mathrm{p}-\mathrm{Si}$} & & $\mathrm{a}-\mathrm{Si}$ & \multicolumn{3}{c}{ CdTe } & \multicolumn{3}{c}{ CIGS } \\
\cline { 2 - 10 } & Exp. & Std. & Exp. & Std. & Exp. & Std. & Exp. & Std. & Exp. & Std. \\
\hline $\mathrm{I}_{\mathrm{sc}}$ & 2.31 & 1.16 & 2.42 & 1.22 & 2.22 & 1.12 & 2.38 & 1.20 & 2.35 & 1.18 \\
$\mathrm{~V}_{\mathrm{oc}}$ & 0.35 & 0.18 & 0.30 & 0.15 & 0.33 & 0.16 & 0.34 & 0.17 & 0.33 & 0.16 \\
$\mathrm{P}_{\mathrm{m}}$ & 2.12 & 1.06 & 2.17 & 1.09 & 2.08 & 1.04 & 1.98 & 0.99 & 1.96 & 0.98 \\
\hline
\end{tabular}

$\alpha_{e}\left(1-\mathrm{R}_{e}\right) I(t) b d x=\left[U_{m a}\left(T_{m}-T_{a}\right)+U_{m r}\left(T_{m}-T_{r}\right)\right] b d x+\eta_{m} I(t) b d x$

[The rate of solar energy absorbed by PV module]

$$
\begin{aligned}
= & {\left[\begin{array}{c}
\text { An overall heat loss from top } \\
\text { surface of PV module to ambient }
\end{array}\right] } \\
& +[\text { An overall heat loss from back side of PV module to test cell }]
\end{aligned}
$$

$+[$ The electrical energy production rate of integrated PV module]

$\alpha_{e}\left(1-\mathrm{R}_{e}\right) I(t)=U_{m a}\left(T_{m}-T_{a}\right)+U_{m r}\left(T_{m}-T_{r}\right)+\eta_{m} I(t)$

$U_{m a}=\left[\sum \frac{l}{k}+\frac{1}{h_{o}}\right]^{-1}, U_{m r}=\left[\sum \frac{l}{k}+\frac{1}{h_{i}}\right]^{-1}$ where, $h_{o}=5.7+3.8 \mathrm{v}$ with $\mathrm{v}=2.5$, and $h_{i}=2.8+3 \mathrm{~V}$ with $\mathrm{V}=0$ (inside test cell) $[2,4,9]$. The design parameters and the specification of test cell used in calculation are tabulated in Table 4 and 5, and the complete details of expressions are available in Appendix A. The thermal conductivity (k), layer thickness (1) of each modules used in the experimentation are shown in Table 4 [30-35]. Temperature dependent electrical efficiency expression for photovoltaic module is given as $[4,46]$,

$\eta_{m}=\eta_{m o}\left[1-\beta_{o}\left(T_{m}-T_{o}\right)\right]$ Where, $\left(T_{m}-T_{o}\right) \geqslant 0$

After substituting the expression of $\eta_{m}$, Eq. (1) become,

$\alpha_{e}\left(1-\mathrm{R}_{e}\right) I(t)+U_{m a} T_{a}+U_{m r} T_{r}-\eta_{m o}-\eta_{m o} \beta_{o} T_{o}=U_{m a} T_{m}+U_{m r} T_{m}-\eta_{m o} \beta_{o} T_{m}$

From Eq. (3), temperature dependent correction coefficient of efficiency, $\beta_{o}$ has order of $10^{-3}$, and efficiency, $\eta_{m o}$ and $U_{a, r}$ has fraction and unit place value respectively $\left(\eta_{m o} \beta_{o} I(t) / U_{a, r}\right) \approx 0[2,28]$. And by using approximation methods, denominator value become almost equal to unity for $0-1000 \mathrm{~W} / \mathrm{m}^{2}$ range of solar intensity and expression for module operating temperature, $\mathrm{T}_{\mathrm{m}}$, will become,

$T_{m}=\frac{\alpha \tau_{e} I(t)+U_{m a} T_{a}+U_{m r} T_{r}}{\left(U_{m a}+U_{m r}\right)}$

substituting Eq. (4) into Eq. (2), then the expression will be,

$\eta_{m}=\eta_{m o}\left[1-\beta_{o}\left\{\frac{\alpha \tau_{e} I(t)+U_{m a} T_{a}+U_{m r} T_{r}}{\left(U_{m a}+U_{m r}\right)}-T_{o}\right\}\right]$

inside room temperature of photovoltaic module integrated test cell,

Table 2

\begin{tabular}{|c|c|}
\hline Uncertainty parameters & Calculation \\
\hline $\begin{array}{l}\text { Temperature }\left(\mathrm{U}_{\mathrm{T}, \text { total }}\right) \\
\text { (Digital thermometer, mercury thermometer, } \\
\text { T-type thermocouples, digital temperature } \\
\text { indicator, junction point and temperature } \\
\text { inhomogenity in reading) }\end{array}$ & $\begin{array}{l}\mathrm{U}_{\mathrm{T}, \text { total }}=\left[\left(\mathrm{U}_{\text {digital }}\right)^{2}+\left(\mathrm{U}_{\text {mercury }}\right)^{2}+\left(\mathrm{U}_{\text {thermocouples }}\right)^{2}+\left(\mathrm{U}_{\text {digi-indicator }}\right)^{2}\left(\mathrm{U}_{\text {junction point }}\right)^{2}+\left(\mathrm{U}_{\text {readings }}\right)^{2}\right]^{1 /} \\
\quad=[0.12+0.22+0.12+0.12+0.12+0.12]^{1 / 2}=0.30\end{array}$ \\
\hline $\begin{array}{l}\text { Air velocity measurement }\left(\mathrm{U}_{\mathrm{A}, \text { total }}\right) \\
\quad \text { (Anemometer and reading error) }\end{array}$ & $\mathrm{U}_{\mathrm{A}, \text { total }}=\left[\left(\mathrm{U}_{\text {Anemometer }}\right)^{2}+\left(\mathrm{U}_{\text {readings }}\right)^{2}\right]^{1 / 2}=\left[(0.1)^{2}+(0.1)^{2}\right]^{1 / 2}=0.14$ \\
\hline $\begin{array}{l}\text { Solar intensity measurement }\left(\mathrm{U}_{\mathrm{S}, \text { total }}\right) \\
\quad \text { (Digital Solarimeter and reading error) }\end{array}$ & $\mathrm{U}_{\mathrm{S}, \text { total }}=\left[\left(\mathrm{U}_{\text {solarimeter }}\right)^{2}+\left(\mathrm{U}_{\text {readings }}\right)^{2}\right]^{1 / 2}=\left[(1)^{2}+(1)^{2}\right]^{1 / 2}=1.4$ \\
\hline $\begin{array}{l}\text { Total uncertainty in experimental observation } \\
\quad\left(U_{\mathrm{O}, \text { total }}\right)\end{array}$ & $\mathrm{U}_{\mathrm{O}, \text { total }}=\left[\left(\mathrm{U}_{\mathrm{T}, \text { total }}\right)^{2}+\left(\mathrm{U}_{\mathrm{A}, \text { total }}\right)^{2}+\left(\mathrm{U}_{\mathrm{S}, \text { total }}\right)^{2}\right]^{1 / 2}=\left[(0.3)^{2}+(0.14)^{2}+(1.4)^{2}\right]^{1 / 2}= \pm \mathbf{1 . 4 3} \%$ \\
\hline
\end{tabular}

Total uncertainty corresponding with the thermal performance of photovoltaic modules integrated on prototype test cells [40] 
Table 4

Design parameters of photovoltaic modules and variable used in calculation during experimentation.

\begin{tabular}{|c|c|c|c|c|c|c|}
\hline Symbols & Units & $\mathrm{m}-\mathrm{Si}$ & $\mathrm{p}-\mathrm{Si}$ & $\mathrm{a}-\mathrm{Si}$ & CdTe & CIGS \\
\hline B & $\mathrm{m}$ & 0.66 & 0.66 & 1.1 & 0.6 & 0.6 \\
\hline $\mathrm{L}$ & $\mathrm{m}$ & 0.796 & 0.875 & 1.3 & 1.2 & 1.2 \\
\hline$\tau_{\mathrm{g}}$ & fraction & 0.95 & 0.95 & 0.95 & 0.95 & 0.95 \\
\hline$\alpha_{c}$ & fraction & 0.9 & 0.9 & 0.85 & 0.9 & 0.9 \\
\hline$\beta_{c}$ & fraction & 0.83 & 0.88 & 1 & 1 & 1 \\
\hline$\alpha_{\tau}$ & fraction & 0.5 & 0.5 & 0 & 0 & 0 \\
\hline $\mathrm{C}_{\mathrm{a}}$ & $\mathrm{kJ} / \mathrm{kg} \mathrm{K}$ & 1.005 & 1.005 & 1.005 & 1.005 & 1.005 \\
\hline $\mathrm{C}_{\mathrm{w}}$ & $\mathrm{kJ} / \mathrm{kg} \mathrm{K}$ & 4.186 & 4.186 & 4.186 & 4.186 & 4.186 \\
\hline$\rho_{\mathrm{w}}$ & $\mathrm{kg} / \mathrm{m}^{3}$ & 1000 & 1000 & 1000 & 1000 & 1000 \\
\hline$\rho_{\mathrm{a}}$ & $\mathrm{kg} / \mathrm{m}^{3}$ & 1.225 & 1.225 & 1.225 & 1.225 & 1.225 \\
\hline$\dot{m}_{w}$ & $\mathrm{~kg} / \mathrm{s}$ & 0.05 & 0.05 & 0.05 & 0.05 & 0.05 \\
\hline $\mathrm{M}_{\mathrm{r}}$ & $\mathrm{kg}$ & 0.686 & 0.686 & 0.686 & 0.686 & 0.686 \\
\hline $\mathrm{R}_{\mathrm{e}}$ & fraction & 0.15 & 0.15 & 0.15 & 0.15 & 0.15 \\
\hline$A_{m}$ & $\mathrm{~m}^{2}$ & 0.484 & 0.5775 & 1.43 & 0.72 & 0.72 \\
\hline$\gamma$ & fraction & 0.5 & 0.5 & 0.5 & 0.5 & 0.5 \\
\hline$v$ & $\mathrm{~m}^{2} / \mathrm{sec}$ & $1.55 \times 10^{-6}$ & $1.55 \times 10^{-6}$ & $1.55 \times 10^{-6}$ & $1.55 \times 10^{-6}$ & $1.55 \times 10^{-6}$ \\
\hline$\vartheta_{\mathrm{w}}$ & $\mathrm{m} / \mathrm{s}$ & 0.25 & 0.25 & 0.25 & 0.25 & 0.25 \\
\hline$P_{r}$ & - & 11.35 & 11.35 & 11.35 & 11.35 & 11.35 \\
\hline $\mathrm{a}$ & - & $2.3 \times 10^{-4}$ & $2.3 \times 10^{-4}$ & $2.3 \times 10^{-4}$ & $2.3 \times 10^{-4}$ & $2.3 \times 10^{-4}$ \\
\hline $1_{\mathrm{Gi}}$ & $\mathrm{m}$ & 0.003 & 0.0035 & 0.0032 & 0.0032 & 0.004 \\
\hline $\mathrm{k}_{\mathrm{Gi}}$ & $\mathrm{W} / \mathrm{mK}$ & 1.8 & 1.8 & 1.8 & 1.8 & 1.8 \\
\hline$l_{\operatorname{arc}}$ & $\mathrm{m}$ & 0.0000001 & 0.0000001 & 0.0000001 & 0.0000001 & 0.0000001 \\
\hline $\mathrm{k}_{\mathrm{arc}}$ & $\mathrm{W} / \mathrm{mK}$ & 32 & 32 & 32 & 32 & 32 \\
\hline $1_{\mathrm{pv}}$ & $\mathrm{m}$ & 0.0003 & 0.000225 & 0.000015 & 0.000012 & 0.00005 \\
\hline $\mathrm{k}_{\mathrm{pv}}$ & $\mathrm{W} / \mathrm{mK}$ & 130 & 148 & 1.5 & 6.2 & 7.3 \\
\hline $1_{\mathrm{ec}}$ & $\mathrm{m}$ & 0.0005 & 0.0005 & 0.000762 & 0.0005 & 0.00775 \\
\hline $\mathrm{k}_{\mathrm{ec}}$ & $\mathrm{W} / \mathrm{mK}$ & 0.35 & 0.35 & 0.35 & 0.35 & 0.35 \\
\hline $1_{\mathrm{rm}}$ & $\mathrm{m}$ & 0.00001 & 0.00001 & 0.00001 & 0.00001 & 0.00001 \\
\hline $\mathrm{k}_{\mathrm{rm}}$ & $\mathrm{W} / \mathrm{mK}$ & 237 & 237 & 237 & 237 & 237 \\
\hline$l_{p}$ & $\mathrm{~m}$ & 0.0001 & 0.0001 & 0.0032 & 0.0032 & 0 \\
\hline $\mathrm{k}_{\mathrm{b}}$ & $\mathrm{W} / \mathrm{mK}$ & 0.2 & 0.2 & 1.8 & 1.8 & 0 \\
\hline
\end{tabular}

Table 5

Test cell parameters used in the experimentation.

\begin{tabular}{lll}
\hline Parameters & Units & Values \\
\hline Inside wall surface $\left(\mathrm{A}_{\mathrm{t}}\right)$ & $\mathrm{m}^{2}$ & 1.46 \\
Inside volume of test cell & $\mathrm{m}^{3}$ & 0.56 \\
Thickness of wood $\left(l_{w}\right)$ & $\mathrm{m}$ & 0.03 \\
Mass of air inside test cell $\left(\mathrm{M}_{\mathrm{r}}\right)$ & $\mathrm{kg}$ & 0.686 \\
Thickness of insulation $\left(l_{i}\right)$ & $\mathrm{m}$ & 0.12 \\
Thermal conductivity of wood $\left(k_{w}\right)$ & $\mathrm{W} / \mathrm{m} \mathrm{K}$ & 0.09 \\
Thermal conductivity of insulation $\left(k_{i}\right)$ & $\mathrm{W} / \mathrm{m} \mathrm{K}$ & 0.022 \\
\hline
\end{tabular}

the energy balance equation will be,

$U_{m r}\left(T_{m}-T_{r}\right) A_{m}=M_{r} C_{a}\left(\frac{d T_{r}}{d t}\right)+U_{t} A_{t}\left(T_{r}-T_{a}\right)$

[The rate of overall heat transfer from module to inside test cell]

$=[$ The rate of heat gain by inside air of test cell $]$

$+[$ The rate of heat loss from inside of test cell through sides ]

Eq. (6) can be shown in terms of first order equation

$\frac{d T_{r}}{d t}+\psi T_{r}=\bar{f}(t)$

$\psi=\left[\frac{(U A)_{t}+U_{m r}\left(1-h_{a 1}\right) A_{m}}{M_{r} C_{a}}\right] \bar{f}(t)=\left[\frac{\alpha \tau_{e} I(t) A_{m} h_{a 1}+\left\{h_{a 1} U_{m a} A_{m}+U_{t} A_{t}\right\} T_{a}}{M_{r} C_{a}}\right] \quad$ and $h_{a 1}=\frac{U_{m r}}{\left(U_{m a}+U_{m r}\right)}$. The solution of first order differential equation, Eq. (7) with boundary condition, at $\left.\mathrm{T}_{\mathrm{r}}\right|_{\mathrm{t}}=0, \mathrm{~T}_{\mathrm{r}}=\mathrm{T}_{\mathrm{ri}}$ and at $\left.\mathrm{T}_{\mathrm{r}}\right|_{\mathrm{t}=\mathrm{t}}, \mathrm{T}_{\mathrm{r}}=\mathrm{T}_{\mathrm{r}}$ is given as,

$T_{r}=\frac{\overline{f(t)}}{\psi}\left(1-e^{-\psi t}\right)+T_{r \mid t=o} e^{-\psi t}$

Case 2: Photovoltaic module integrated on test cell with water flow.

For photovoltaic module with water flow, the energy balance equation for solar cell of photovoltaic module can be written as,

$\alpha_{e}\left(1-R_{e}\right) I(t)=U_{m w}\left(T_{m}-T_{w}\right)+U_{m r}\left(T_{m}-T_{r}\right)+\eta_{m} I(t)$

[The rate of solar energy absorbed by PV module]

$=$ [An overall heat lossfrom top surface of PV to water layer $]$

+ [An overall heat loss from back side of PV to test cell ]

+ [The electrical energy production rate of integrated PV module]

After substituting Eq. (2) in Eq. (9), and with implication of approximation method, $\eta_{m o} \beta_{0} I(t) /\left(U_{m w}+U_{m r}\right) \approx 0$, The expression for photovoltaic module operating temperature integrated on test cell with water flow.

$T_{m}=\frac{\alpha \tau_{e} I(t)+U_{m w} T_{w}+U_{m r} T_{r}}{\left(U_{m w}+U_{r}\right)}$

As water flowing over the photovoltaic module integrated on test cell, the heat is dissipated and the energy balance equation can be written as,

$U_{m w}\left(T_{m}-T_{w}\right) b d x=\dot{m}_{w} c_{w}\left(\frac{d T_{w}}{d x}\right) d x+h_{t w}\left(T_{w}-T_{a}\right) b d x$

[The rate of overall heat transfered from PV module to flowing fluid]

$=$ [The rate of heat gain by water flowing over the PV module $]$

+ [The rate of heat loss from water to ambient ]

Here, the value of $U_{m w}$ correspond to overall heat transfer from photovoltaic module to thin layer of flowing water, $U_{m w}=0.0332(K w / L) \mathrm{R}_{e l}^{1 / 2} \mathrm{P}_{r}^{1 / 3}$, and $\mathrm{R}_{e l}=\vartheta_{w} L / \nu$ [25,28]. Since, the surface water flow was maintained a constant laminar flow over the entire length of PV modules. Therefore, Nusselt numbers have been used for calculating heat transfer coefficient [28]. Similarly, $h_{t w}$ refers to $h_{t w}=h_{r w}+h_{c w}+h_{e w}$, and their used expressions are shown in Appendix A $[2,25,28]$. By putting the expression of photovoltaic 
module operating temperature into the first left side term of Eq. (11), and after simplification the expression become,

$U_{m w}\left(T_{m}-T_{w}\right) b d x=U_{e f f, a} \alpha \tau_{e} I(t) b d x+U_{m e f f}\left(T_{r}-T_{w}\right) b d x$

where $U_{e f f, a}=\frac{U_{m w}}{\left(U_{m w}+U_{m r}\right)}, U_{m e f f}=\left[\frac{1}{U_{m w}}+\frac{1}{U_{m r}}\right]^{-1}$ and $U_{e f f, b}=\frac{U_{m r}}{\left(U_{m w}+U_{m r}\right)}$, After substituting Eq. (12) in Eq. (11), the simplification of Eq. (11) in terms of first order differential equation,

$$
\begin{gathered}
\left(\frac{d T_{w}}{d x}\right)+\frac{1}{\dot{m}_{w} c_{w}}\left(h_{t w}+U_{m e f f}\right) \\
T_{w} b=\frac{1}{\dot{m}_{w} c_{w}}\left[U_{e f f, a} \alpha \tau_{e} I(t)+U_{m e f f} T_{r}\right. \\
\left.+h_{t w} T_{a}\right] b
\end{gathered}
$$

First order differential equation with boundary condition, at $T_{w}||_{x}=$ $o, T_{w}=T_{w i}$ and at $\left.T_{w}\right|_{x=L}, T_{w}=T_{w o}$.

$$
\begin{aligned}
T_{w \mid x=L}= & {\left[\frac{U_{\text {eff }, a} \alpha \tau_{e} I(t)+U_{\text {meff }} T_{r}+h_{t w} T_{a}}{h_{t w}+U_{\text {meff }}}\right]\left[1-\exp \left(-\frac{b\left(h_{t w}+U_{\text {meff }}\right) L}{\dot{m}_{w} c_{w}}\right)\right] } \\
& +T_{w \mid x=0} \exp \left(-\frac{b\left(h_{t w}+U_{\text {meff }}\right) L}{\dot{m}_{w} c_{w}}\right)
\end{aligned}
$$

average flowing water (thin film) temperature over the length of the photovoltaic module can be obtained by using Eq. (14),

$$
\begin{aligned}
\overline{T_{w}}= & \frac{1}{L} \int_{0}^{L} T_{w} d x=\left[\frac{U_{\text {eff }, a} \alpha \tau_{e} I(t)+U_{\text {meff }} T_{r}+h_{t w} T_{a}}{h_{t w}+U_{\text {meff }}}\right][1 \\
& \left.-\frac{1-\exp \left(-\frac{b\left(h_{t w}+U_{\text {meff }}\right) L}{\dot{m}_{w} c_{w}}\right)}{\frac{b\left(h_{t w}+U_{\text {meff }}\right) L}{\dot{m}_{w} c_{w}}}\right]+T_{w \mid x=0}\left[\frac{1-\exp \left(-\frac{b\left(h_{t w}+U_{\text {meff }}\right) L}{\dot{m}_{w} c_{w}}\right)}{\frac{b\left(h_{t w}+U_{m e f f}\right) L}{\dot{m}_{w} c_{w}}}\right]
\end{aligned}
$$

as thermal energy transferred from photovoltaic module to inside of test cell, their energy balance can be written as,

$U_{m r}\left(T_{m}-T_{r}\right) A_{m}=M_{r} C_{a}\left(\frac{d T_{r}}{d t}\right)+U_{t} A_{t}\left(T_{r}-T_{a}\right)$

[The rate of overall heat transfered from PV module to test cell]

$$
\begin{aligned}
= & {\left[\begin{array}{c}
\text { The rate of heat gain from PV module toinside of test } \\
\text { cell (for space heating) }
\end{array}\right] } \\
& +[\text { The rate of heat loss from inside of test cell to ambient }]
\end{aligned}
$$

$U_{m r}=\left[\sum \frac{l}{k}+\frac{1}{h_{i}}\right]^{-1}$ and $h_{i}=2.8+3 \mathrm{~V}[2,9]$. For inside of test cell, the air velocity becomes zero, $V=0$. After substituting Eq. (10) into Eq. (16), then the expression becomes,

$U_{m r}\left(T_{m}-T_{r}\right) A_{m}=U_{e f f, b} \alpha \tau_{e} I(t) b d x+U_{m e f f}\left(T_{w}-T_{r}\right) b d x$

$U_{e f f, b}=\frac{U_{m r}}{\left(U_{m w}+U_{m r}\right)}$ and $U_{m e f f}=\left[\frac{1}{U_{m w}}+\frac{1}{U_{m r}}\right]^{-1}$, substituting Eq. (17) into Eq. (16),

$$
\begin{gathered}
\left(\frac{d T_{r}}{d t}\right)+\frac{1}{M_{r} C_{a}}\left(U_{t} A_{t}+U_{m e f f} A_{m}\right) T_{r}=\frac{1}{M_{r} C_{a}}\left[U_{e f f, b} \alpha \tau_{e} I(t) A_{m}+U_{m e f f} T_{w} A_{m}\right. \\
\left.+U_{t} A_{t} T_{a}\right]
\end{gathered}
$$

The solution of first order differential equation with boundary condition, at $\left.\mathrm{T}_{\mathrm{r}}\right|_{\mathrm{t}=0}, \mathrm{~T}_{\mathrm{r}}=\mathrm{T}_{\mathrm{ri}}$ and at $\left.\mathrm{T}_{\mathrm{r}}\right|_{\mathrm{t}=\mathrm{t}}, \mathrm{T}_{\mathrm{r}}=\mathrm{T}_{\mathrm{r}}$ is given as,

$T_{r}=\frac{D(t)}{\xi}\left(1-e^{-\xi t}\right)+T_{r \mid t=0} e^{-\xi t}$

$\xi=\frac{1}{M_{r} C_{a}}\left(U_{t} A_{t}+U_{\text {meff }} A_{m}\right), D(t)=\frac{1}{M_{r} C_{a}}\left[U_{\text {eff }, b} \alpha \tau_{e} I(t) A_{m}+U_{\text {meff }} T_{w} A_{m} \quad\right.$ by $\left.+U_{t} A_{t} T_{a}\right]$

incorporating Eqs. (10) and (15), the expression for temperature dependent electrical efficiency of photovoltaic module by using Eq. (2) can be obtained as, $\eta_{m}=\eta_{m o}\left[1-\beta_{o}\left\{\begin{array}{l}\frac{\alpha \tau_{e} I(t)}{\left(U_{m w}+U_{m r}\right)}+\left[\frac{U_{e f f, a}^{2} \tau_{e} I(t)+U_{e f f, b} h_{t w} T_{a}}{h_{t w}+U_{m e f f}}\right][1-\chi] \\ +U_{e f f, a} T_{w \mid x=0}[\chi]+\left(U_{e f f, b}+U_{e f f, a} h_{b 2}[1-\chi]\right) T_{r}-T_{o}\end{array}\right\}\right]$

$\phi=\frac{b\left(h_{t w}+U_{m e f f}\right) L}{\dot{m}_{w} c_{w}}, h_{b 2}=\frac{U_{\text {meff }}}{\left(h_{t w}+U_{\text {meff }}\right)}$ and $\chi=\frac{1-\exp (-\phi)}{\phi}$, From Eq. (20), the expression of electrical efficiency, $\eta_{m}$, includes the effect of mass flow rate of water, $\dot{m}_{w}$ as well as test cell room temperature, $T_{r}$ and this expression is valid for all types of photovoltaic modules. To calculate electrical efficiency of photovoltaic module, following expression is used [29],

$\eta_{m}=\frac{I_{s c} V_{o c} F F}{A_{m} I(t)}=\frac{P_{m}}{A_{m} I(t)}$

the following expression used to calculate the useful thermal energy $\left(\mathrm{Q}_{\mathrm{u}}\right)[27,28]$,

Case (1), $\dot{Q}_{u 1}=M_{r} C_{a} \frac{d T_{r}}{d t}$

Here, the thermal energy corresponds to inside room (air) temperature rise of photovoltaic module integrated test cell with respect to ambient temperature.

Case (2), $\dot{Q}_{u 2}=M_{r} C_{a} \frac{d T_{r}}{d t}+\dot{m}_{w} C_{w}\left(T_{w}-T_{w i}\right)$

Here, thermal energy correspond to sum of incremental difference in water $\left(T_{w}\right)$ after water flowing over photovoltaic module and inside room (air) temperature $\left(T_{r}\right)$ test cell rise. In theoretical calculation, Eqs. (8) and (19) for test cell room temperature, $T_{r}$ were incorporated into Eqs. (22) and (23) respectively for thermal gain along with Eq. (15) for surface flowing water temperature, $\mathrm{T}_{\mathrm{w}}$ was used in Eq. (23) for surface water temperature rise in case 2. Similarly, instantaneous thermal efficiency $\left(\eta_{t h}\right)$ can be calculated for both cases,

$\eta_{t h}=\left(\frac{\dot{Q}_{u}}{A_{m} I(t)}\right)$

Overall thermal efficiency $\left(\eta_{\text {over,th }}\right)$ can be represented a sum of instantaneous thermal efficiency and electrical efficiency equivalent to thermal efficiency $\left(\gamma_{m}=0.38\right.$ for quality of coal) $[12,25-28]$.

$\eta_{\text {over }, t h}=\eta_{t h}+\frac{\eta_{m}}{\gamma_{m}}$

For Case 1, thermal energy correspond to space heating of test cell using Carnot efficiency factor by converting thermal efficiency to equivalent electrical efficiency $[25,47]$. Case 2 incorporate both space and water heating. The overall exergy efficiency for different cases has been calculated as follows,

For case (1), $\eta_{\text {over }, \mathrm{ex}}=\eta_{m}+\eta_{t h 1}\left(1-\frac{T_{a}+273}{T_{r}+273}\right)$

For case (2), $\eta_{\text {over, }, x}=\eta_{m}+\eta_{t h 1}\left(1-\frac{T_{a}+273}{T_{r}+273}\right)+\eta_{t h 2}\left(1-\frac{T_{a}+273}{T_{m}+273}\right)$

Here, two scenarios are consider by changing the mass flow rate, $\dot{m}_{w}$, (i) very large and (ii) small. Now both the events are discussed below [25].

Scenario (i). For large mass flow rate $\left(\dot{m}_{w} \rightarrow \infty\right)$ and $T_{w \mid x=0}=T_{a}$, then $\chi=\frac{1-\exp (-\phi)}{\phi}=1$, Eq. (20) can be expressed as,

$\eta_{m}=\eta_{m o}\left[1-\beta_{o}\left\{\frac{\alpha \tau_{e} I(t)}{\left(U_{m w}+U_{m r}\right)}+U_{e f f, a} T_{a}+U_{e f f, b} T_{r}-T_{o}\right\}\right]$

for large mass flow rate, e.g. $\dot{m}_{w}=0.80 \mathrm{~kg} / \mathrm{sec}$, The observed photovoltaic module electrical efficiencies were $13.38 \%, 11.42 \%, 6.14 \%$, $6.48 \%$, and $7.94 \%$ for $\mathrm{m}-\mathrm{Si}, \mathrm{p}-\mathrm{Si}, \mathrm{a}-\mathrm{Si}, \mathrm{CdTe}$ and CIGS respectively that 
correspond to maximum measured value in this case. In that scenario observed instantaneous thermal efficiency of m-Si, p-Si, a-Si, CdTe and CIGS were $12.48 \%, 10.87 \%, 8.2 \%, 12.78 \%$ and $12.12 \%$ respectively by using Eqs. (26) and (27).

Scenario (ii). For small mass flow rate $\left(\dot{m}_{w} \rightarrow 0\right)$, then $\chi=\frac{1-\exp (-\phi)}{\phi}=0$ and Eq. (20) give following expression,

$$
\begin{aligned}
\eta_{m}= & \eta_{m o}\left[1-\beta_{o}\left\{\frac{\alpha \tau_{e} I(t)}{\left(U_{m w}+U_{r}\right)}+\left[\frac{U_{e f f, a}^{2} \alpha \tau_{e} I(t)+U_{e f f, a} h_{t w} T_{a}}{h_{t w}+U_{m e f f}}\right]\right.\right. \\
& \left.\left.+\left(U_{e f f, b}+U_{e f f, a} h_{b 2}\right) T_{r}-T_{o}\right\}\right]
\end{aligned}
$$

With negligible mass flow rate $\dot{m}_{w}=0.001 \mathrm{~kg} / \mathrm{sec}$, the observed photovoltaic modules efficiency were $11.10 \%, 9.46 \%, 5.42 \%, 5.88 \%$ and $6.28 \%$ for $\mathrm{m}-\mathrm{Si}, \mathrm{p}-\mathrm{Si}, \mathrm{a}-\mathrm{Si}, \mathrm{CdTe}$ and CIGS respectively. For that scenario, observed instantaneous thermal efficiency of m-Si, p-Si, a-Si, CdTe and CIGS were $6.2 \%, 7.07 \%, 7.24 \%, 7.65 \%$ and $8.19 \%$ respectively by using Eqs. (23) and (24).

\subsection{Constant room temperature mode operation}

In present study, for a constant room (test cell) temperature mode needs $T_{r}=25^{\circ} \mathrm{C}=$ constant. To achieve $T_{r}=25^{\circ} \mathrm{C}=$ constant, an expression for mass flow rate, $\dot{m}_{w}$ has been derived from Eq. (14),

$$
\begin{aligned}
\dot{m}_{w}= & \frac{b\left(h_{t w}+U_{\text {meff }}\right) L}{c_{w}\left[\log \left\{T_{w i}-\left(\frac{U_{e f f, a} \alpha \tau_{e} I(t)+U_{\text {meff }} T_{r}+h_{t w} T_{a}}{h_{t w}+U_{\text {meff }}}\right)\right\}\right.} \\
& \left.-\log \left\{T_{w o}-\left(\frac{U_{\text {eff }, a} \alpha \tau_{e} I(t)+U_{\text {meff }} T_{r}+h_{t w} T_{a}}{h_{t w}+U_{\text {meff }}}\right)\right\}\right]
\end{aligned}
$$

above equation is suitable to attain optimize mass flow rate for a given constant room (test cell) temperature, $\mathrm{T}_{\mathrm{r}}$.

\subsection{Characteristic curve and equations}

This physical system reflects building integrated photovoltaic thermal system and integration of photovoltaic modules over the insulated test cell correspond to space heating or air heating. Therefore, it will act as a conventional collector irrespective of cooling surface water flow. The effectiveness of photovoltaic thermal system over a building or a test cell for space heating can be defined by using Hottel-WhillerBliss (HWB) equation known as characteristic equation [2,16,25,28],

$\eta_{h}=F_{R}(\alpha \tau)-F_{R} U_{L}\left(\frac{T_{m}-T_{a}}{I(t)}\right)$

$\eta_{h}$ shows the corresponding thermal and electrical efficiency of the characteristic equation, $F_{R}$ and $F_{R} U_{L}$ show the gain factor and loss coefficient for thermal and electrical efficiency for all cases, and $\mathrm{T}_{\mathrm{m}}$ represents average operating temperature of modules.

\subsection{Correlation coefficient and root mean square percent deviation (RMSD)}

For the evaluating the model performance and comparative analysis between theoretically calculated and experimentally observed value the following expression has been used [48],

Correlation coefficient, $r=\frac{N \sum X_{i} Y_{i}-\left(\sum X_{i}\right)\left(\sum Y_{i}\right)}{\sqrt{N \sum X_{i}^{2}-\left(\sum X_{i}^{2}\right)^{2}} \sqrt{N \sum Y_{i}^{2}-\left(\sum Y_{i}\right)^{2}}}$

\footnotetext{
$r>0$ positive linear relationship.

$r<0$ negative linear relationship.

$r=0$ implies no linear relationship between two variables.
}

Root mean square percent deviation (RMSD), $e=\sqrt{\frac{\sum\left(e_{i}\right)^{2}}{N}}$ $e_{i}=\left[\frac{X_{i}-Y_{i}}{X_{i}}\right] \times 100, Y_{i}$ (experimental values of variables), and $X_{i}$ (the-
oretical values of variables).

\section{Methodology}

The experiments were performed on two typical consecutive days in April 2017 on the rooftop of the building in Indian Institute of Technology (IIT) Delhi campus, New Delhi. The experiments were executed on clear sky conditions (blue sky) when the ratio of daily diffuse radiation to daily global radiation are less than or equal to 0.25 , and the sunshine hours is greater than or equal to $9 \mathrm{~h}$. On second day of experiment, a thin film of water was introduced by maintaining constant flow rate for which five $2.5 \mathrm{~mm}$ diameter tubes with 46 holes each were placed on the top of photovoltaic modules integrated on test cells. After adding the water by casual pipe from water tank, feeding tube released water through holes which continued to flow over the upper surface of photovoltaic modules as a thin film. The parametric value of all type photovoltaic modules such as short circuit current, $\mathrm{I}_{\mathrm{sc}}$, open circuit voltage, $\mathrm{V}_{\mathrm{oc}}$ and module efficiency, $\eta_{m}$ as well as incident normal solar intensity, $\mathrm{I}(\mathrm{t})$, air velocity, test cell room temperature, $\mathrm{T}_{\mathrm{r}}$, water temperature at both side, $\mathrm{T}_{\mathrm{wi}} / \mathrm{T}_{\mathrm{wo}}$, and ambient temperature, $\mathrm{T}_{\mathrm{a}}$ were measured regularly with interval time, $15 \mathrm{~min}$. Therefore, the experimental evaluation relied on $15 \mathrm{~min}$ average measurement. The experimentally observed solar intensity, $\mathrm{I}(\mathrm{t})$ and ambient temperature, $\mathrm{T}_{\mathrm{a}}$ was used for theoretical measurement of modules operating temperature, $\mathrm{T}_{\mathrm{m}}$ by Eqs. (4) and (10), test cell rooms temperature, $\mathrm{T}_{\mathrm{r}}$ by Eqs. (8) and (19), surface flowing water temperature, $\mathrm{T}_{\mathrm{wo}} / \mathrm{T}_{\mathrm{wi}}$ by Eq. (15), and temperature dependent electrical efficiency by Eqs. (5) and (20) for both cases, and these values were compared with experimentally observed values. Eq. (21) was used for experimental observation of electrical efficiency of photovoltaic modules in both cases. The useful thermal energy, $\dot{Q}_{u}$ was calculated using Eqs. (22) and (23) for cases 1 and 2 respectively. Similarly, instantaneous thermal efficiency, overall thermal efficiency and overall exergy efficiency was calculated by using Eqs. (25)-(27) respectively. To determine the potential effects on Fill factor, FF for both with and without water cases (both day of experiments) at different intensity, the current, $\mathrm{I}_{\mathrm{sc}}$ and Voltage, $\mathrm{V}_{\mathrm{oc}}$ were measured at five different point of varying load $0-5 \mathrm{~K} \Omega$ connected with photovoltaic modules. The formula $\dot{m}_{w}=\rho_{w} a v$, where $\rho_{w}$ is water density, a is opening area from which water flown over the PV modules and $\mathrm{v}$ is the water velocity, was applied to measure mass flow rate of water, $\dot{m}_{w}$. For measuring water velocity, $\mathrm{v}(\mathrm{m} / \mathrm{s})$, the volume of water filled in 1 min was measured and converted into cubic meter divided by area of through which water flown $[25,28]$.

\section{Electrical performance in alternative reference condition (ARC)}

In outdoor environment, experimentally measured electrical parameters were incomparable with the given reference data sheet at STC for different photovoltaic modules. Therefore, the experimentally observed electrical parameters $\mathrm{I}_{\mathrm{sc}}, \mathrm{V}_{\mathrm{oc}}$ and $\mathrm{P}_{\mathrm{m}}$ were interpreted in specific pre-specified alternating reference condition (ARC) by using translational equation by considering IEC 6089 method 1 and 2 . The electrical parameters $\mathrm{I}_{\mathrm{sc}}, \mathrm{V}_{\mathrm{oc}}, \mathrm{P}_{\mathrm{m}}$ are interpreted in standard test condition (STC) i.e. Solar intensity, $1000 \mathrm{~W} / \mathrm{m}^{2}$, module temperature, $25^{\circ} \mathrm{C}$, using translation equation as follows $[41,49-51]$,

$V_{o c, A R C}=V_{o c, o}+\omega_{V}\left(T_{A R C}-T_{m}\right)$

$I_{s c, A R C}=I_{s c, o}\left(\frac{I_{A R C}(t)}{I(t)}\right)+\omega_{I}\left(T_{A R C}-T_{m}\right)$

$P_{\mathrm{m}, A R C}=V_{o c, A R C} \times F F \times I_{s c, A R C}$ 
measured parameter to the reference rated values of PV modules. Here, the current and voltage parameters were measured to calculate power, $\mathrm{P}_{\mathrm{m}}$ in irradiance range of $300-400 \mathrm{~W} / \mathrm{m}^{2}, 500-600 \mathrm{~W} / \mathrm{m}^{2}$, and $700-800 \mathrm{~W} / \mathrm{m}^{2}$, and that is translated to the power, $\mathrm{P}_{\mathrm{m}}$ at ARC for $350 \mathrm{~W} / \mathrm{m}^{2}, 550 \mathrm{~W} / \mathrm{m}^{2}$ and $750 \mathrm{~W} / \mathrm{m}^{2}$ respectively at $25^{\circ} \mathrm{C}$ module operating temperature, $\mathrm{T}_{\mathrm{m}}$. In order to observe the parameters for all photovoltaic modules, cleaning procedure was performed to remove any dust accumulated over the surface glass of photovoltaic modules. Since temperature coefficients depend upon the photovoltaic modules technology, Makrides et al. [36] observed the temperature coefficient for 13 different technology based photovoltaic modules in real ambient condition of Germany and Cyprus. During our observation, temperature coefficients of $\mathrm{V}_{\mathrm{oc}}, \omega_{V}$ correspond to $-0.32 \% / \mathrm{K},-0.38 \% / \mathrm{K},-0.31 \%$ / $\mathrm{K},-0.36 \% / \mathrm{K}$ and $-0.24 \% / \mathrm{K}$ for $\mathrm{m}-\mathrm{Si}, \mathrm{p}-\mathrm{Si}$, a-Si, CdTe and CIGS respectively similarly for $\mathrm{I}_{\mathrm{sc}}$, temperature coefficient, $\omega_{I}$ corresponding to $0.03 \% / \mathrm{K}, 0.02 \% / \mathrm{K}, 0.05 \% / \mathrm{K}, 0.04 \% / \mathrm{K}$ and $0.03 \% / \mathrm{K}$ respectively are considered. All the work programming and mathematical calculations introduced in the experiment was executed in "Matlab11" software.

\section{Results and discussion}

Experiments were executed on the rooftop of building situated at IIT Delhi, the variation of incident solar intensity on photovoltaic modules and ambient temperature are shown in Fig. 4. A minimal difference was observed among two consecutive day's solar intensity and ambient temperature with deviation of about $r=0.98$ and 0.97 , and $e=1.1$, and 1.34 respectively [52,53]. The parameters measured at regular interval of time are tabulated in Table 6. For all photovoltaic modules, $I_{s c}$ decreases with water flow as observed in without water case attributed to solar irradiance obstruction by thin film by the continuous water flow. However, significant variances were observed in $\mathrm{V}_{\text {oc }}$ and $\mathrm{FF}$ value due to water flow. This phenomenon can be understood as surface water flow on photovoltaic modules cause substantial decrease in module operating temperature, $\mathrm{T}_{\mathrm{m}}$ resulting increase in $\mathrm{V}_{\mathrm{oc}}$. The experimentally measured and theoretical calculated values of electrical efficiency, $\eta_{m}$ of photovoltaic modules for both with and without water flow are shown in Fig. 5. Correlation coefficient, $r$ and root mean square percent deviation, $e$ are used to analyse the deviation between experimentally observed value and theoretically calculated results. The values of $r$ ranges from 0.9 to 0.98 , likewise the values of $e$ are in range of 2.3-3.6. Thus, it can be concluded that the fair agreement is achieved between theoretically calculated and experimental observations in both cases. Fig. 6 shows the comparative variation of electrical efficiency of five different photovoltaic modules integrated on test cells for both with and without surface water flow. Daily average electrical efficiencies of photovoltaic modules namely; m-Si, p-Si, a-Si, CdTe and CIGS with water flow on top are found to be $12.30 \%, 10.98 \%, 6.08 \%, 6.60 \%$ and $7.71 \%$, and without water case values are $11.41 \%, 10.30 \%, 5.86 \%$, $6.26 \%$ and $6.90 \%$ respectively. Here, the maximum fractional changes $\Delta \eta_{m} / \eta_{m w o}=\left(\eta_{m w}-\eta_{m w o}\right) / \eta_{m w o}$ (where, electrical efficiency without water, $\eta_{m w o}$ electrical efficiency with water, $\eta_{m w}$ ) are observed in CIGS with a value of $10.40 \%$ followed by $\mathrm{m}-\mathrm{Si}, \mathrm{p}$-Si, CdTe and a-Si with values $7.755,6.62 \%, 5.41 \%$ and $3.76 \%$ respectively. The variation in electrical efficiencies for both cases can easily be interpreted with the help of observing variation in photovoltaic modules operating temperature, $\mathrm{T}_{\mathrm{m}}$ as shown in Fig. 7 . The maximum daily average module operating temperature, $\mathrm{T}_{\mathrm{m}}$ is attained by CIGS with a value of $58^{\circ} \mathrm{C}$ followed by CdTe, a-Si, p-Si and a-Si with values $54^{\circ} \mathrm{C}, 53{ }^{\circ} \mathrm{C}, 50{ }^{\circ} \mathrm{C}$, $49.8^{\circ} \mathrm{C}$ respectively in without water case. While in 'with water flow case', all the photovoltaic modules attained almost the same $T_{m}$ value of $36^{\circ} \mathrm{C}$, and again maximum fluctuation in $\mathrm{T}_{\mathrm{m}}$ value is observed in CIGS. This means that CIGS technology is more sensitive towards module operating temperature, $\mathrm{T}_{\mathrm{m}}$ as compared to other photovoltaic technologies. Along with heat dissipation, reflection losses due to water flow on the top of photovoltaic modules also play an important role. Reflection losses directly affect photovoltaic modules performance. The refractive index of water $(n=1.3)$ lies in between of air $(n=1)$ and EVA $(n=1.49-1.52)$. The water flowing on the upper surface of photovoltaic modules helps to reduce reflection losses by $2 \%$ to $3 \%$ that will further assist in improvement of electrical efficiency of photovoltaic modules. In order to calculate the reflection coefficient $(R)$ for air to EVA, air to water and water to EVA, we use Fresnel equation [25,28,29], $R=\left(\frac{n_{1}-n_{2}}{n_{1}+n_{2}}\right)^{2}$ where $\mathrm{R}$ is the reflection coefficient (R) for two medium, and $\mathrm{n}_{1}$ and $\mathrm{n}_{2}$ are refractive index of two mediums, their values correspond $0.043,0.017$ and 0.006 respectively. The reflection coefficient of air to EVA exhibits large reflection losses, and this can be reduced to a great degree with water flowing on the top surface.

Fig. 8 shows the variation of electrical yields and open circuit voltages of photovoltaic modules with time of day for both cases. All photovoltaic modules get affected by water flow, and exhibit more output than without water cases. As the operating temperature of photovoltaic modules increased, the corresponding average open circuit voltage of $\mathrm{m}-\mathrm{Si}, \mathrm{p}-\mathrm{Si}$, a-Si, CdTe and CIGS decreased with $0.023 \%$, $0.013 \%, 0.18 \%, 0.19 \%, 0.10 \%$ per ${ }^{\circ} \mathrm{C}$ rise in operating temperature. Similarly power output drops due to the rise in operating temperature correspond to $0.16 \%, 0.15 \%, 0.10 \%, 0.07 \%$ and $0.13 \%$ per ${ }^{\circ} \mathrm{C}$ rise for $\mathrm{m}-\mathrm{Si}, \mathrm{p}-\mathrm{Si}$, a-Si, CdTe and CIGS modules respectively. All photovoltaic modules get affected by thermal annealing and light soaking effect $[27,33,54]$. The hourly average electrical yields generated by photovoltaic modules are found to be $31.41 \mathrm{~W}, 33.61 \mathrm{~W}, 46.23 \mathrm{~W}, 25.28 \mathrm{~W}$ and $29.51 \mathrm{~W}$ for $\mathrm{m}-\mathrm{Si}, \mathrm{p}-\mathrm{Si}$, a-Si, CdTe and CIGS with water flow, similarly, for without water case, the corresponding values are $29.08 \mathrm{~W}$, $31.26 \mathrm{~W}, 44.48 \mathrm{~W}, 23.97 \mathrm{~W}$ and $26.49 \mathrm{~W}$ respectively. Here, the initially rated value of photovoltaic modules is almost equal to stabilized value in outdoor condition. The experimentally observed $P_{m}$ value is translated to alternative reference condition (ARC) for $\mathrm{I}(\mathrm{t})$ at $350 \mathrm{~W} /$ $\mathrm{m}^{2}, 550 \mathrm{~W} / \mathrm{m}^{2}$ and $750 \mathrm{~W} / \mathrm{m}^{2}$ respectively and $\mathrm{T}_{\mathrm{m}}=25^{\circ} \mathrm{C}$. The daily average instant electrical yields, $\mathrm{P}_{\mathrm{m}}$ of photovoltaic modules with and without surface water flow, and their root means square percent deviation (RMSD) with respect to the rated data sheet of modules at ARC are tabulated in Table 7 . The results indicate that the performances of photovoltaic modules are better at low irradiance level for both cases. Further, $\mathrm{P}_{\mathrm{m}}$ values of photovoltaic modules at solar intensity $350 \mathrm{~W} /$ $\mathrm{m}^{2}, 550 \mathrm{~W} / \mathrm{m}^{2}$ and $750 \mathrm{~W} / \mathrm{m}^{2}$ demonstrate increasing deviation from the rated values [51]. Photovoltaic modules without water flow experienced more deviation from rated data sheet values as compared to modules with surface water flow.

Fig. 9 shows the observed variation of instantaneous thermal efficiencies and overall thermal efficiencies of photovoltaic modules integrated on test cells. As specific heat of water is very high as compared to air, the heat gain by running thin film of water played a crucial role in thermal energy analysis. Observed temperature on both sides of water flow and temperature rise in inside of test cells, $\mathrm{T}_{\mathrm{r}}$ are tabulated in Table 6. Daily average instantaneous thermal efficiency of photovoltaic modules are found to be $18.32 \%, 17 \%, 10.4 \%, 20.43 \%, 18.52 \%$

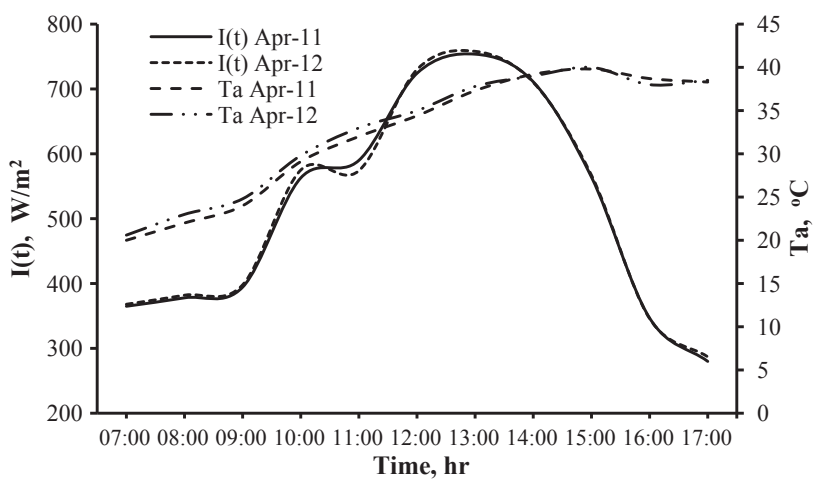

Fig. 4. Experimentally observed incident solar radiation, $\mathrm{I}(\mathrm{t})$ and ambient temperature, $\mathrm{T}_{\mathrm{a}}$ with time on two consecutive typical day of April 2016. 
Table 6

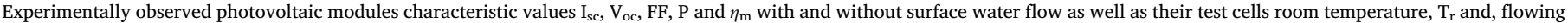
water $\mathrm{T}_{\mathrm{wi}}$ and $\mathrm{T}_{\text {wo }}$.

\begin{tabular}{|c|c|c|c|c|c|c|c|c|c|c|c|c|c|c|}
\hline \multirow{2}{*}{$\begin{array}{l}\text { Time } \\
\text { (hr) }\end{array}$} & \multicolumn{2}{|l|}{$\mathrm{I}_{\mathrm{sc}}(\mathrm{A})$} & \multicolumn{2}{|c|}{$\mathrm{V}_{\mathrm{oc}}(\mathrm{V})$} & \multicolumn{2}{|c|}{ FF (\%) } & \multicolumn{2}{|c|}{$\mathrm{P}_{\mathrm{m}}(\mathrm{W})$} & \multicolumn{2}{|c|}{$\eta_{\mathrm{m}}(\%)$} & \multicolumn{2}{|l|}{$\mathrm{T}_{\mathrm{r}}\left({ }^{\circ} \mathrm{C}\right)$} & \multirow[t]{2}{*}{$\mathrm{T}_{\mathrm{wi}}\left({ }^{\circ} \mathrm{C}\right)$} & \multirow[t]{2}{*}{$\mathrm{T}_{\text {wo }}\left({ }^{\circ} \mathrm{C}\right)$} \\
\hline & $\begin{array}{l}\text { With } \\
\text { water }\end{array}$ & $\begin{array}{l}\text { Without } \\
\text { water }\end{array}$ & $\begin{array}{l}\text { With } \\
\text { water }\end{array}$ & $\begin{array}{l}\text { Without } \\
\text { water }\end{array}$ & $\begin{array}{l}\text { With } \\
\text { water }\end{array}$ & $\begin{array}{l}\text { Without } \\
\text { water }\end{array}$ & $\begin{array}{l}\text { With } \\
\text { water }\end{array}$ & $\begin{array}{l}\text { Without } \\
\text { water }\end{array}$ & $\begin{array}{l}\text { With } \\
\text { water }\end{array}$ & $\begin{array}{l}\text { Without } \\
\text { water }\end{array}$ & $\begin{array}{l}\text { With } \\
\text { water }\end{array}$ & $\begin{array}{l}\text { Without } \\
\text { water }\end{array}$ & & \\
\hline \multicolumn{15}{|l|}{$m$-si } \\
\hline 07:00 & 1.9 & 2.1 & 19.4 & 19.2 & 0.64 & 0.55 & 23.44 & 22.25 & 13.16 & 12.49 & 20.6 & 20.6 & 20 & 20.75 \\
\hline 08:00 & 2 & 2.1 & 19.4 & 19.2 & 0.62 & 0.57 & 24.06 & 22.82 & 13.02 & 12.34 & 23 & 23.1 & 22 & 23.45 \\
\hline 09:00 & 2.1 & 2.3 & 19.4 & 19.2 & 0.61 & 0.53 & 24.83 & 23.54 & 12.9 & 12.22 & 24.8 & 24.9 & 24 & 25.55 \\
\hline $10: 00$ & 2.8 & 3.1 & 19.2 & 18.9 & 0.75 & 0.63 & 40.58 & 37 & 12.54 & 11.41 & 29.8 & 30 & 29.1 & 31.05 \\
\hline $11: 00$ & 2.9 & 3 & 19 & 18.7 & 0.62 & 0.57 & 34.23 & 31.81 & 12.35 & 11.45 & 33.1 & 33.2 & 32 & 34.8 \\
\hline $12: 00$ & 3.2 & 3.4 & 18.9 & 18.6 & 0.71 & 0.62 & 42.91 & 38.96 & 12.18 & 11.03 & 35.1 & 35.3 & 34.4 & 37.24 \\
\hline $13: 00$ & 3.4 & 3.5 & 18.8 & 18.2 & 0.69 & 0.62 & 43.84 & 39.74 & 11.99 & 10.83 & 38 & 38.2 & 37.3 & 40.55 \\
\hline $14: 00$ & 3.1 & 3.3 & 18.4 & 18.1 & 0.72 & 0.63 & 41.04 & 37.36 & 11.98 & 10.87 & 39.2 & 39.4 & 39.2 & 40.84 \\
\hline $15: 00$ & 2.6 & 2.8 & 18.4 & 18 & 0.69 & 0.61 & 32.78 & 30.52 & 11.97 & 11.12 & 40.3 & 40.5 & 39.8 & 41.35 \\
\hline $16: 00$ & 2.1 & 2.3 & 18.5 & 18.2 & 0.52 & 0.47 & 20.29 & 19.56 & 12.13 & 11.68 & 38.3 & 38.6 & 38.7 & 39.15 \\
\hline $17: 00$ & 1.8 & 1.9 & 18.6 & 18.1 & 0.50 & 0.48 & 16.84 & 16.36 & 12.13 & 11.78 & 38.8 & 39.1 & 38.3 & 39.3 \\
\hline \multicolumn{15}{|l|}{$p-S i$} \\
\hline 07:00 & 1.8 & 2.1 & 19.2 & 19 & 0.72 & 0.69 & 24.91 & 23.71 & 11.72 & 11.16 & 20.6 & 20.6 & 20 & 20.76 \\
\hline 08:00 & 2.1 & 2.2 & 19.2 & 19.1 & 0.64 & 0.61 & 25.62 & 24.36 & 11.61 & 11.04 & 23 & 23.1 & 22 & 23.47 \\
\hline 09:00 & 2.3 & 2.4 & 19.4 & 19.3 & 0.59 & 0.57 & 26.46 & 25.15 & 11.51 & 10.94 & 24.8 & 24.9 & 24 & 25.6 \\
\hline $10: 00$ & 2.9 & 3.3 & 19.3 & 19 & 0.78 & 0.72 & 43.41 & 39.74 & 11.22 & 10.27 & 29.9 & 30 & 29.1 & 31.1 \\
\hline $11: 00$ & 3 & 3.3 & 19.1 & 18.8 & 0.64 & 0.61 & 36.71 & 34.19 & 11.07 & 10.31 & 33.1 & 33.3 & 32 & 34.8 \\
\hline $12: 00$ & 3.2 & 3.6 & 18.8 & 18.6 & 0.77 & 0.71 & 46.1 & 42 & 10.94 & 9.96 & 35.1 & 35.4 & 34.4 & 37.3 \\
\hline $13: 00$ & 3.1 & 3.4 & 18.6 & 18.3 & 0.82 & 0.76 & 47.21 & 42.91 & 10.78 & 9.8 & 38 & 38.3 & 37.3 & 40.7 \\
\hline $14: 00$ & 3 & 3.3 & 18.4 & 18.3 & 0.80 & 0.73 & 44.18 & 40.35 & 10.77 & 9.84 & 39.3 & 39.6 & 39.2 & 40.9 \\
\hline $15: 00$ & 2.8 & 3 & 18.2 & 18 & 0.69 & 0.65 & 35.26 & 32.91 & 10.77 & 10.05 & 40.3 & 40.6 & 39.8 & 41.4 \\
\hline $16: 00$ & 2.2 & 2.4 & 18.4 & 18.2 & 0.54 & 0.52 & 21.79 & 21.01 & 10.91 & 10.52 & 38.4 & 38.7 & 38.7 & 39.2 \\
\hline $17: 00$ & 1.9 & 2 & 18.4 & 18.2 & 0.52 & 0.51 & 18.07 & 17.57 & 10.9 & 10.6 & 38.9 & 39.3 & 38.3 & 39.4 \\
\hline$a-S i$ & & & & & & & & & & & & & & \\
\hline 07:00 & 0.66 & 0.67 & 120 & 116 & 0.42 & 0.42 & 33.3 & 32.41 & 6.33 & 6.16 & 20.6 & 20.7 & 20 & 20.8 \\
\hline 08:00 & 0.67 & 0.7 & 122 & 117 & 0.42 & 0.41 & 34.4 & 33.47 & 6.3 & 6.13 & 23 & 23.2 & 22 & 23.5 \\
\hline 09:00 & 0.69 & 0.72 & 124 & 120 & 0.42 & 0.40 & 35.68 & 34.71 & 6.27 & 6.1 & 24.9 & 25.1 & 24 & 25.7 \\
\hline $10: 00$ & 0.74 & 0.8 & 128 & 124 & 0.63 & 0.57 & 59.26 & 56.54 & 6.19 & 5.9 & 30 & 30.3 & 29.1 & 31.3 \\
\hline $11: 00$ & 0.81 & 0.97 & 124 & 122 & 0.50 & 0.41 & 50.45 & 48.58 & 6.15 & 5.92 & 33.3 & 33.7 & 32 & 35.1 \\
\hline $12: 00$ & 0.97 & 1.04 & 122 & 120 & 0.54 & 0.49 & 63.75 & 60.69 & 6.11 & 5.81 & 35.4 & 35.9 & 34.4 & 37.5 \\
\hline $13: 00$ & 1.01 & 1.02 & 120 & 117 & 0.54 & 0.52 & 65.75 & 62.53 & 6.07 & 5.77 & 38.3 & 39 & 37.3 & 40.9 \\
\hline $14: 00$ & 0.98 & 1.01 & 118 & 116 & 0.53 & 0.50 & 61.55 & 58.69 & 6.06 & 5.78 & 39.6 & 40.5 & 39.2 & 41.3 \\
\hline $15: 00$ & 0.76 & 0.8 & 118 & 115 & 0.55 & 0.52 & 49.18 & 47.4 & 6.07 & 5.85 & 40.8 & 41.7 & 39.8 & 41.5 \\
\hline $16: 00$ & 0.58 & 0.63 & 118 & 114 & 0.44 & 0.41 & 30.21 & 29.61 & 6.11 & 5.98 & 38.9 & 39.8 & 38.7 & 39.3 \\
\hline $17: 00$ & 0.56 & 0.59 & 116 & 114 & 0.39 & 0.37 & 25.06 & 24.67 & 6.11 & 6.01 & 39.5 & 40.5 & 38.3 & 39.5 \\
\hline CdTe & & & & & & & & & & & & & & \\
\hline 07:00 & 0.77 & 0.79 & 49 & 47 & 0.49 & 0.48 & 18.38 & 17.72 & 6.94 & 6.69 & 20.6 & 20.6 & 20 & 20.9 \\
\hline 08:00 & 0.78 & 0.8 & 50 & 49 & 0.49 & 0.47 & 18.96 & 18.26 & 6.89 & 6.64 & 23 & 23.1 & 22 & 23.7 \\
\hline 09:00 & 0.8 & 0.87 & 52 & 50 & 0.47 & 0.43 & 19.64 & 18.91 & 6.85 & 6.6 & 24.8 & 25 & 24 & 25.9 \\
\hline $10: 00$ & 0.92 & 0.95 & 56 & 52 & 0.63 & 0.62 & 32.48 & 30.44 & 6.73 & 6.31 & 29.9 & 30.1 & 29.1 & 31.5 \\
\hline $11: 00$ & 0.9 & 0.92 & 52 & 50 & 0.59 & 0.57 & 27.59 & 26.19 & 6.68 & 6.34 & 33.1 & 33.4 & 32 & 35.6 \\
\hline $12: 00$ & 1.12 & 1.15 & 50 & 47 & 0.62 & 0.60 & 34.79 & 32.5 & 6.62 & 6.18 & 35.2 & 35.5 & 34.4 & 38.1 \\
\hline $13: 00$ & 1.2 & 1.23 & 47 & 44 & 0.64 & 0.62 & 35.82 & 33.4 & 6.56 & 6.12 & 38.1 & 38.4 & 37.3 & 41.2 \\
\hline $14: 00$ & 1.17 & 1.2 & 45 & 42 & 0.64 & 0.62 & 33.53 & 31.38 & 6.56 & 6.14 & 39.3 & 39.8 & 39.2 & 41.5 \\
\hline $15: 00$ & 0.98 & 1 & 42 & 40 & 0.65 & 0.64 & 26.79 & 25.46 & 6.56 & 6.24 & 40.4 & 40.9 & 39.8 & 41.8 \\
\hline $16: 00$ & 0.9 & 0.98 & 43 & 40 & 0.43 & 0.41 & 16.49 & 16.05 & 6.62 & 6.44 & 38.5 & 39 & 38.7 & 39.6 \\
\hline $17: 00$ & 0.72 & 0.75 & 44 & 42 & 0.43 & 0.43 & 13.68 & 13.39 & 6.62 & 6.48 & 39 & 39.6 & 38.3 & 39.7 \\
\hline CIGS & & & & & & & & & & & & & & \\
\hline 07:00 & 0.62 & 0.65 & 67 & 65 & 0.53 & 0.48 & 21.92 & 20.41 & 8.27 & 7.7 & 20.6 & 20.7 & 20 & 20.9 \\
\hline 08:00 & 0.64 & 0.68 & 68 & 66 & 0.52 & 0.47 & 22.52 & 20.94 & 8.19 & 7.62 & 23 & 23.1 & 22 & 23.7 \\
\hline 09:00 & 0.68 & 0.72 & 70 & 68 & 0.49 & 0.44 & 23.26 & 21.6 & 8.12 & 7.54 & 24.8 & 25 & 24 & 25.9 \\
\hline $10: 00$ & 0.88 & 0.92 & 72 & 69 & 0.60 & 0.53 & 38.12 & 33.44 & 7.9 & 6.93 & 29.9 & 30.1 & 29.1 & 31.3 \\
\hline $11: 00$ & 0.9 & 0.94 & 70 & 67 & 0.51 & 0.46 & 32.23 & 28.99 & 7.8 & 7.01 & 33.1 & 33.4 & 32 & 35.2 \\
\hline $12: 00$ & 1.04 & 1.06 & 67 & 65 & 0.58 & 0.51 & 40.44 & 35.15 & 7.69 & 6.69 & 35.2 & 35.5 & 34.4 & 37.7 \\
\hline $13: 00$ & 1.09 & 1.12 & 66 & 62 & 0.58 & 0.52 & 41.4 & 35.83 & 7.59 & 6.56 & 38.1 & 38.5 & 37.3 & 41.2 \\
\hline $14: 00$ & 1.01 & 1.04 & 62 & 61 & 0.62 & 0.53 & 38.75 & 33.82 & 7.58 & 6.62 & 39.3 & 39.8 & 39.2 & 41.4 \\
\hline $15: 00$ & 0.88 & 0.92 & 61 & 60 & 0.58 & 0.51 & 30.97 & 27.91 & 7.59 & 6.84 & 40.4 & 41 & 39.8 & 41.6 \\
\hline $16: 00$ & 0.6 & 0.7 & 62 & 60 & 0.52 & 0.43 & 19.16 & 18.12 & 7.69 & 7.27 & 38.4 & 39.1 & 38.7 & 39.5 \\
\hline $17: 00$ & 0.57 & 0.65 & 62 & 60 & 0.45 & 0.39 & 15.9 & 15.21 & 7.69 & 7.36 & 39 & 39.6 & 38.3 & 39.6 \\
\hline
\end{tabular}

of $\mathrm{m}-\mathrm{Si}, \mathrm{p}-\mathrm{Si}, \mathrm{a}-\mathrm{Si}, \mathrm{CdTe}$ and CIGS respectively with water flow case whereas for without water case, their corresponding values are $7.8 \%$, $8.07 \%, 8.44 \%, 8.85 \%$ and $9.49 \%$ respectively. Since surface area or aperture area of installed photovoltaic modules on test cells are not equal with each other so before considering their corresponding thermal energy their surface areas need to be considered. The maximum daily average instantaneous thermal efficiency per unit surface area $\left(\mathrm{m}^{2}\right)$ is attained by $\mathrm{m}$-Si modules with values $37.86 \%$ followed by p-Si, CdTe, CIGS and a-Si with $29.50 \%, 28.38 \%, 25.72 \%$ and $7.28 \%$ for with water flow. For without water flow case, $\mathrm{m}-\mathrm{Si}, \mathrm{p}-\mathrm{Si}$, a-Si, CdTe and CIGS have value $16.13 \%, 13.97 \%, 5.89 \%, 12.29 \%$ and $13.18 \%$ respectively where except CIGS all other photovoltaic modules have 

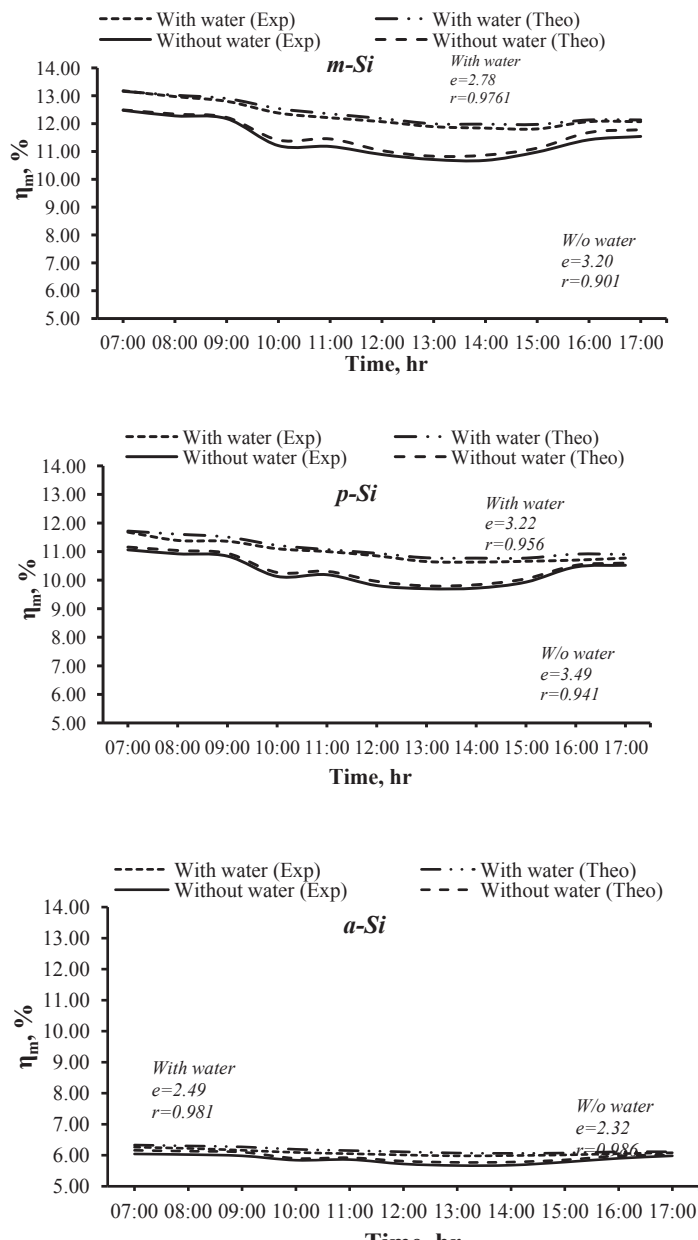

Time, hr
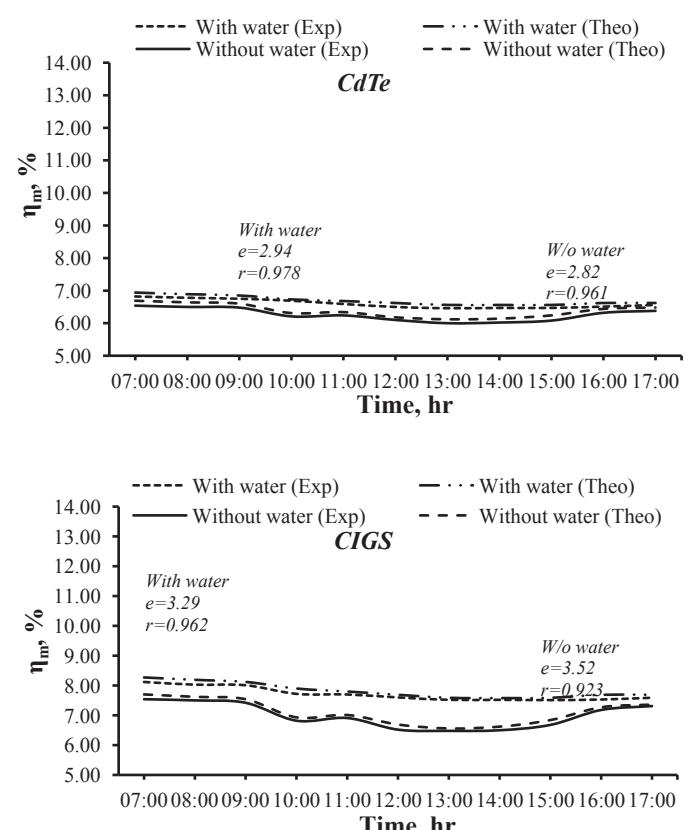

Time, hr

Fig. 5. Experimentally observed and theoretically calculated electrical efficiency, $\eta_{m}$ of photovoltaic modules integrated on test cells with and without surface water flow; m-Si, p-Si, a-Si, CdTe and CIGS.

followed same variation pattern in thermal energy as followed with water case. This variance in CIGS can easily be understood from module operating temperature corresponding to maximum value in without

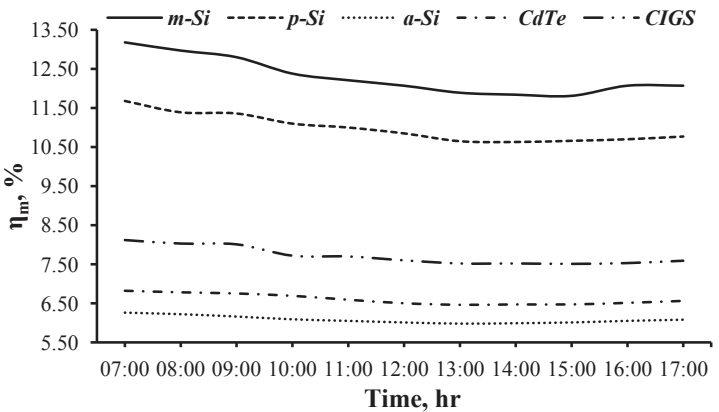

(a)

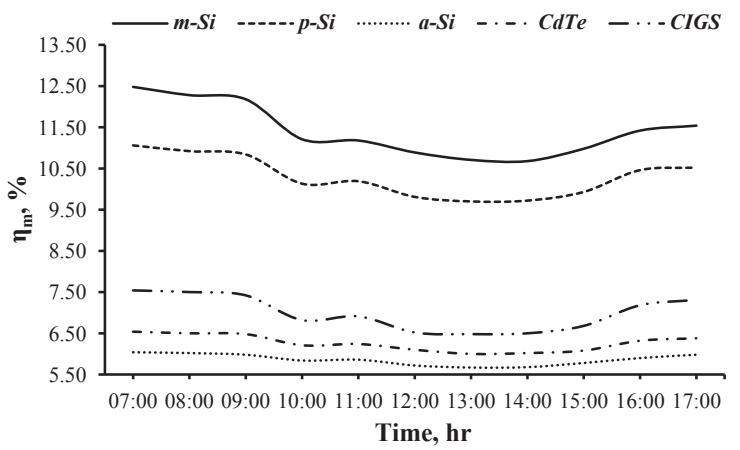

(b)

Fig. 6. Comparative variation of electrical efficiency for photovoltaic modules integrated on test cells; (a) with surface water flow, and (b) without water flow.

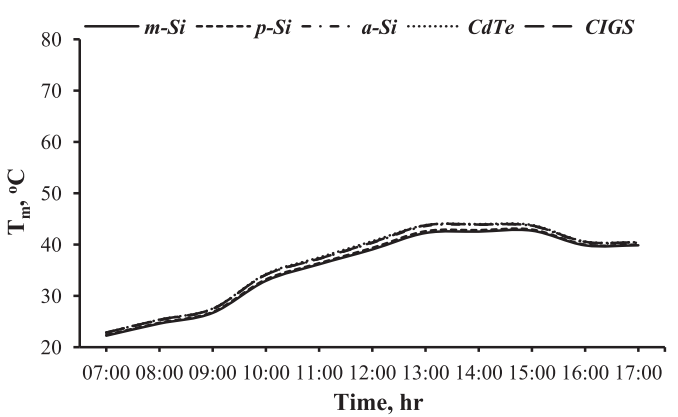

(a)

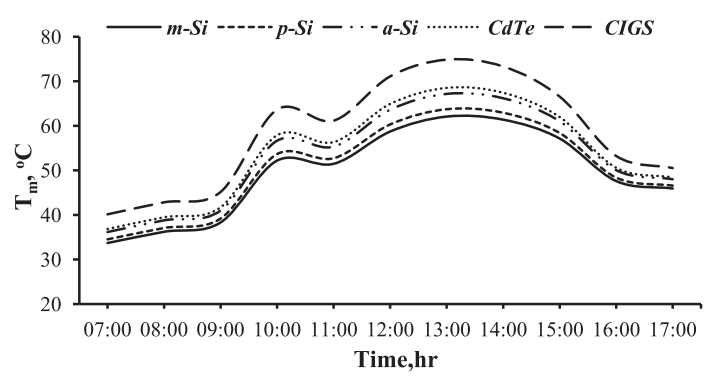

(b)

Fig. 7. Experimentally observed operating temperature, $\mathrm{T}_{\mathrm{m}}$ of photovoltaic modules integrated on test cells; (a) with water, and (b) without surface water flow.

water case as shown in Fig. 6. Daily average overall thermal energy of photovoltaic modules with water flow are detected to be $60.61 \%$, $55.90 \%, 33.57 \%, 60.47 \%$ and $56.56 \%$ for $\mathrm{m}-\mathrm{Si}, \mathrm{p}-\mathrm{Si}$, a-Si, CdTe and CIGS respectively, and for without water case detected values are $32.12 \%, 31.64 \%, 28.12 \%, 29.68 \%$ and $32.08 \%$ respectively.

Fig. 10 shows the comparative variation of overall exergy efficiencies for photovoltaic modules. In both cases, overall exergy efficiency of $\mathrm{m}$-Si module performs better than other photovoltaic 

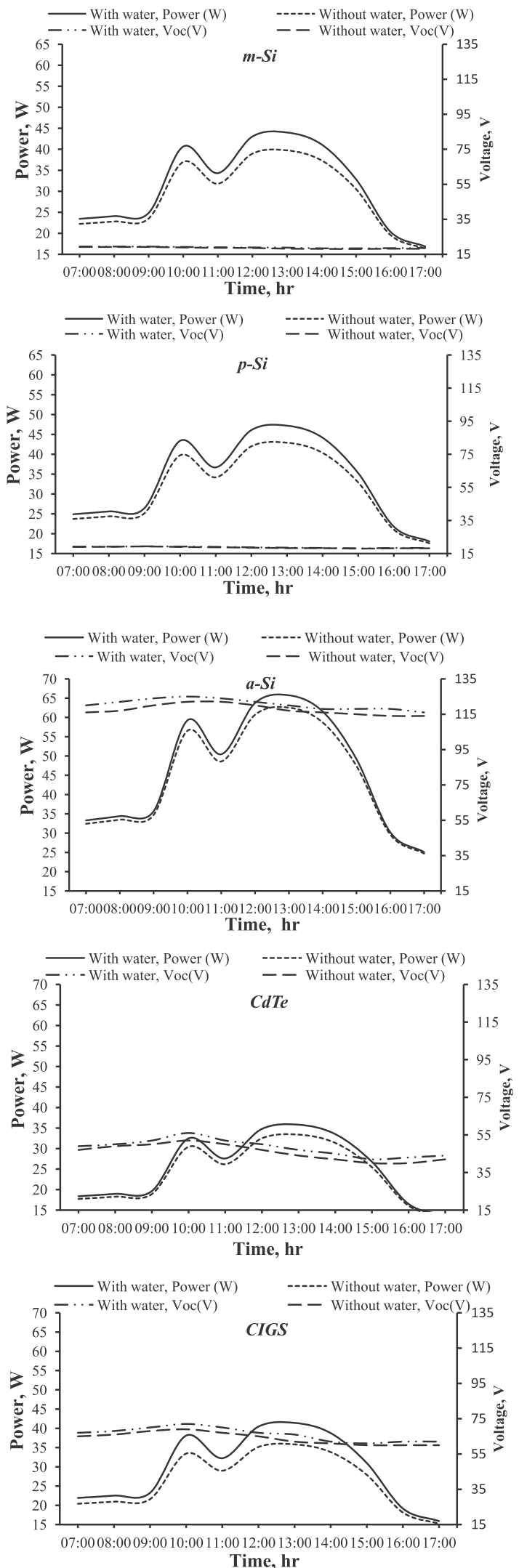

Fig. 8. Experimentally observed maximum yield generated and open circuit voltage of photovoltaic modules integrated on test cells with and without surface water flow; m-Si, p-Si, a-Si, CdTe and CIGS.

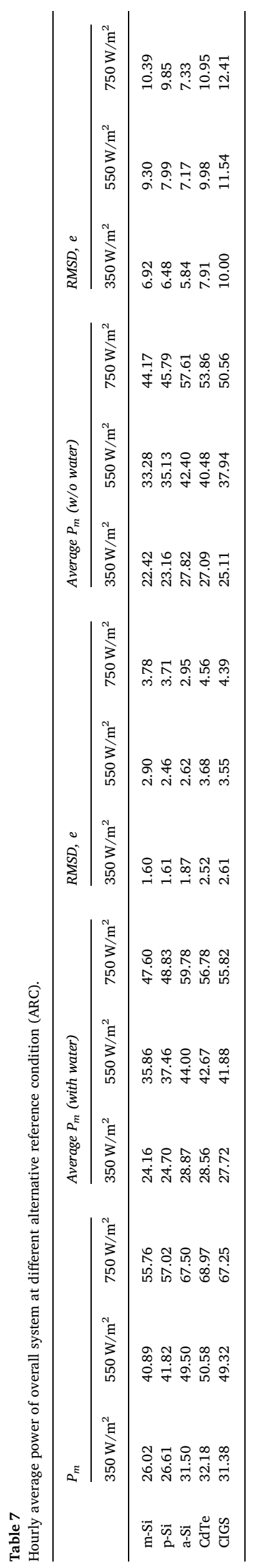



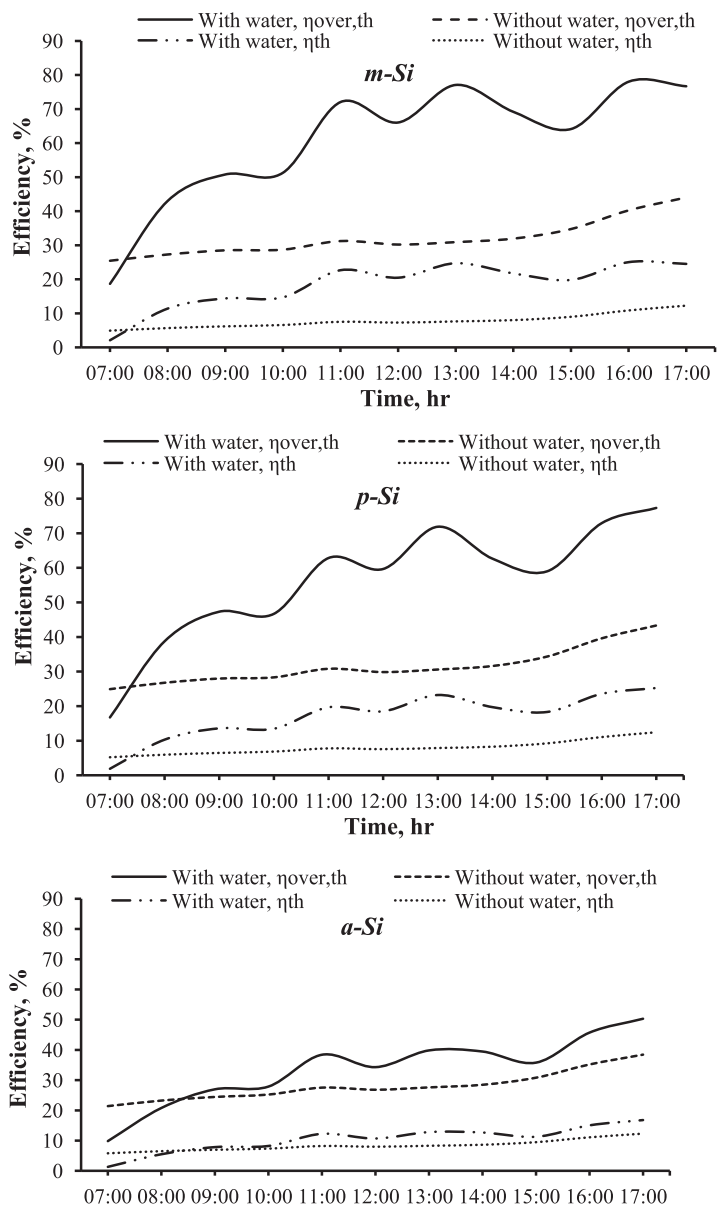

Time, hr

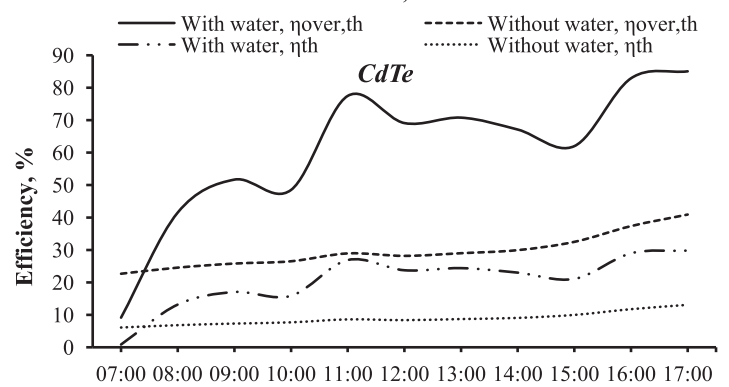

Time, hr

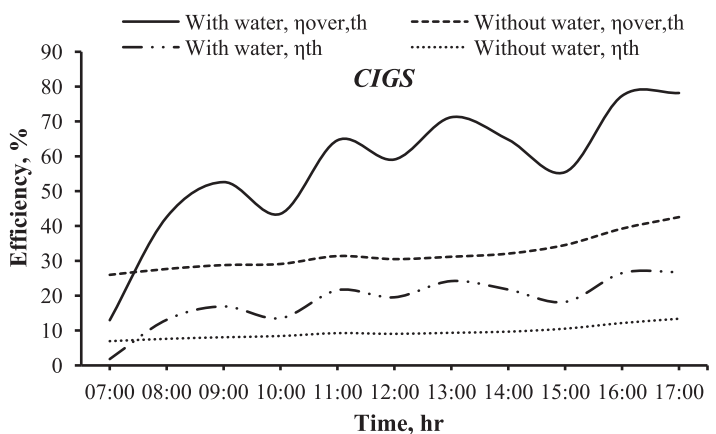

Fig. 9. Experimentally observed instantaneous thermal efficiency, $\eta_{t h}$ and overall thermal efficiency, $\eta_{\text {over, th }}$ of photovoltaic modules integrated on test cells with and without surface water flow; m-Si, p-Si, a-Si, CdTe and CIGS.

modules. Daily average maximum overall exergy efficiency is achieved by $\mathrm{m}$-Si followed by $\mathrm{p}$-Si, CIGS, CdTe and a-Si with $12.52 \% 11.24 \%$, $8 \%, 6.9 \%$ and $6.24 \%$ respectively for with water flow case, and this

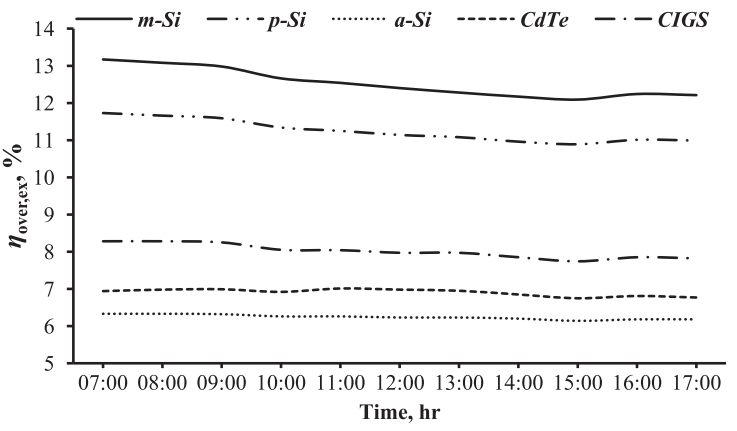

(a)

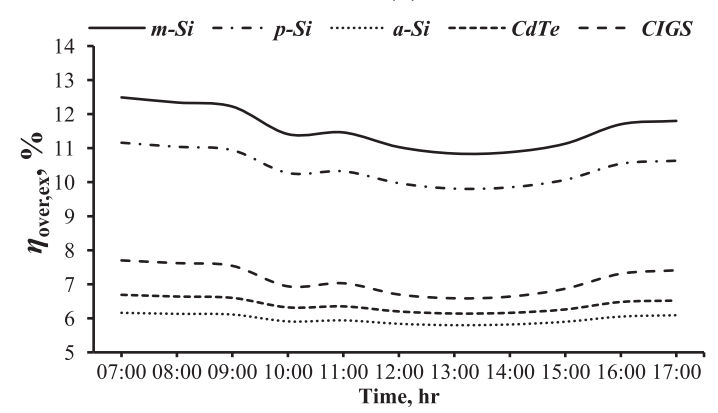

(b)

Fig. 10. Comparative variation of overall electrical efficiency (exergy), $\eta_{\text {over, } \text { ex }}$ for photovoltaic modules integrated on test cells; (a) with surface water flow, and (b) without water flow.

phenomenon remain unaltered for without water flow with values $11.575,10.41 \%, 7.12 \%, 6.39 \%$ and $5.97 \%$ respectively.

In constant collection temperature mode for a conventional flat plate collector, mass flow rate, $\dot{m}_{w}$ of water increases with the time of day due to solar irradiance and ambient condition [55]. Fig. 11 shows that mass flow rate remained almost independent with increasing solar irradiance, $\mathrm{I}(\mathrm{t})$ due to inside room temperature of insulated test cells continuously adding up during day time and the mass flow removes that added heat inside test cell and helps to overcome the phenomenon of solar irradiance. At the beginning time of experiment, test cells room temperatures were almost equal to ambient due to which mass flow rate, $\dot{m}_{w}$ increased to achieve desired test cell temperature. Once the desired temperature inside test cell is achieved, mass flow rate task is to overcome the effect of solar irradiance because the test cell is insulated, and except top heat loss no heat loss is observed along with desired test cell temperature.

Fig. 12 shows the variation of electrical efficiency, $\eta_{m}$ and thermal efficiency, $\eta_{t h}$ of photovoltaic modules for both with and without water flow as a function of $\left(\mathrm{T}_{\mathrm{m}}-\mathrm{T}_{\mathrm{a}}\right) / \mathrm{I}(\mathrm{t})$. With increase in $\left(\mathrm{T}_{\mathrm{m}}-\mathrm{T}_{\mathrm{a}}\right) / \mathrm{I}(\mathrm{t})$

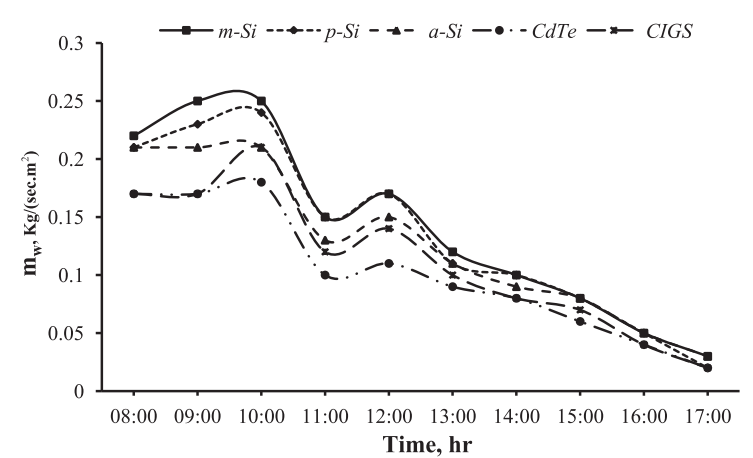

Fig. 11. Hourly variation of mass flow rate, $\dot{m}_{w}$ of surface water flow on photovoltaic modules integrated over test cells to achieve constant room (test cell) temperature mode at $\mathrm{T}_{\mathrm{r}}=25^{\circ} \mathrm{C}$. 

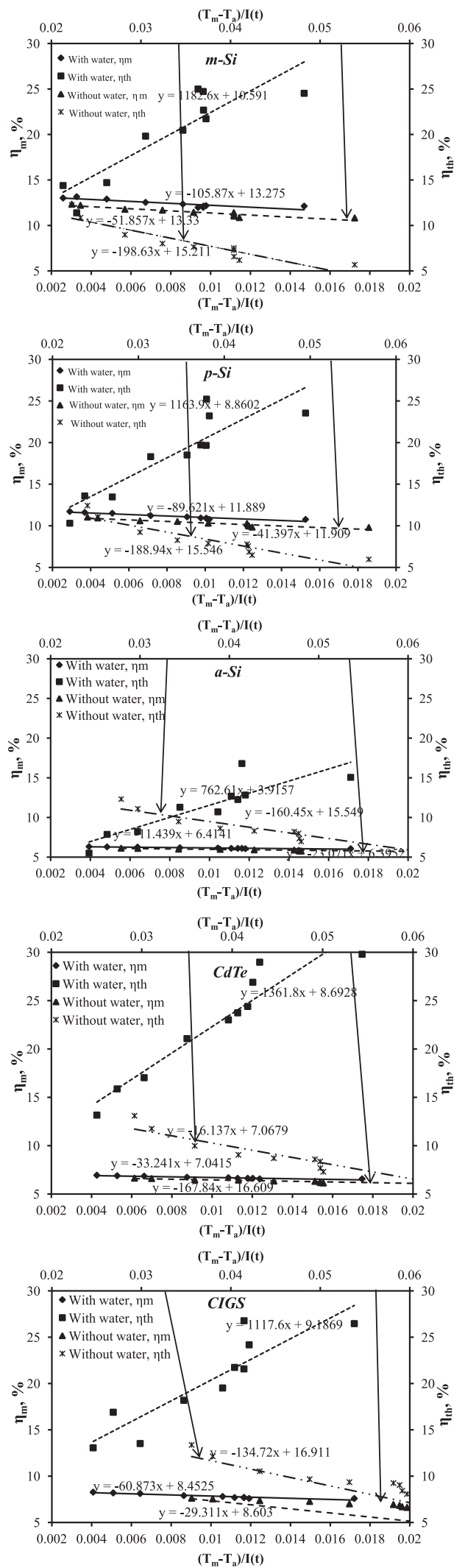

Fig. 12. Variation of electrical efficiency, $\eta_{m}$ and thermal efficiency, $\eta_{t h}$ for photovoltaic modules integrated on test cells with and without surface water flow as a function of $\left(\mathrm{T}_{\mathrm{m}}-\mathrm{T}_{\mathrm{a}}\right) / \mathrm{I}(\mathrm{t}) ; \mathrm{m}-\mathrm{Si}, \mathrm{p}-\mathrm{Si}$, a-Si, CdTe and CIGS.

value, electrical efficiency for all photovoltaic modules show negative trends, though with different rates. The electrical efficiency of photovoltaic modules shows a significant growth in case of with water flow than without water case. Fig. 12 also highlights the variation of thermal efficiency with increment in $\left(\mathrm{T}_{\mathrm{m}}-\mathrm{T}_{\mathrm{a}}\right) / \mathrm{I}(\mathrm{t})$ for both cases. Like electrical efficiency of each photovoltaic modules, thermal efficiency with water flow does not show negative trends albeit their value increase with increasing value of $\left(\mathrm{T}_{\mathrm{m}}-\mathrm{T}_{\mathrm{a}}\right) / \mathrm{I}(\mathrm{t})$. However, thermal efficiency of photovoltaic modules without water shows negative curve with increase of $\left(\mathrm{T}_{\mathrm{m}}-\mathrm{T}_{\mathrm{a}}\right) / \mathrm{I}(\mathrm{t})$. The solid lines as show in Fig. 12 are linear fit trend line giving statistical regression of electrical and thermal efficiency with $\left(\mathrm{T}_{\mathrm{m}}-\mathrm{T}_{\mathrm{a}}\right) / \mathrm{I}(\mathrm{t})$ for all photovoltaic modules along with their corresponding linear equations. These lines show the characteristic curve of all photovoltaic modules with their respective values. Photovoltaic modules with water flow show positive sign due to heat loss from photovoltaic modules to water which is opposite to Hottel-Whiller Bliss equations of a flat plate collector, whereas, photovoltaic modules without water flow follow the same equation [25,55-57]. Their gain factor and loss coefficient of thermal and electrical efficiency for all cases in both seasonal condition are summarized in Table 8 [55,57]. This is because of maximum upward heat loss due to water flow over the surface of photovoltaic modules, and the performance of flat plate collector depends upon minimising the upward heat loss.

\section{Conclusion}

To understand the efficacy of Building integrated photovoltaicthermal (BiPVT) system, five different commercial technologies based photovoltaic modules are integrated on five prototype identically insulated test cells and their performance are studied with and without thin film of water flow on the front surface of photovoltaic modules. An analytical expression is also developed for electrical efficiency in both cases. This mathematical model is further validated with a series of experimental investigation on photovoltaic modules namely; monocrystalline silicon (m-Si), polycrystalline (p-Si), amorphous thin film (a$\mathrm{Si}$ ), cadmium telluride thin film (CdTe) and copper indium gallium selenide (CIGS). Theoretically calculated results show fair agreement with the experimental observation. All photovoltaic modules attain low temperature with water flow than without water flow and exhibit higher electrical efficiency. In case of water flow, thermal energy stored inside test cells went down in all photovoltaic modules due to the rise in flowing water temperature as upward heat gain by water. This helps to enhance thermal efficiency of overall system in form of space heating (air heating) and water heating, whereas, without water flow, the available thermal energy is used only in space heating form via conduction through photovoltaic modules. Daily average electrical efficiency of test cells integrated $\mathrm{m}-\mathrm{Si}$, p-Si, a-Si, CdTe and CIGS photovoltaic modules with and without water flow on them are found to be $12.30 \%, 10.98 \%, 6.08 \%, 6.60 \%$ and $7.71 \%$, and $11.41 \%, 10.30 \%$, $5.86 \%, 6.26 \%$ and $6.99 \%$ respectively. Maximum fractional change with respect to without water case in daily average electrical yield is observed in CIGS with $11 \%$ followed by $\mathrm{m}-\mathrm{Si}$, p-Si, CdTe and a-Si with $8 \%, 7.5 \%, 5.4 \%$ and $4 \%$ respectively. Daily average instantaneous thermal efficiency of photovoltaic modules are found to be $18.32 \%$, $17 \%, 10.4 \%, 20.43 \%, 18.52 \%$ of $\mathrm{m}-\mathrm{Si}, \mathrm{p}-\mathrm{Si}, \mathrm{a}-\mathrm{Si}, \mathrm{CdTe}$ and CIGS respectively with water flow case whereas for without water case, their corresponding values are $7.8 \%, 8.07 \%, 8.44 \%, 8.85 \%$ and $9.49 \%$ respectively. Each photovoltaic module integrated over test cell exhibits almost double overall thermal efficiency with water flow compared to without water case. $\mathrm{m}$-Si module attained maximum daily average overall exergy for both with and without water case with values $12.5 \%$ and $11.5 \%$ respectively followed by $\mathrm{p}-\mathrm{Si}, \mathrm{CIGS}$, CdTe and a-Si values for both cases.

To achieve thermal comfort or desired temperature, mass flow rate of surface water flow should be optimized as per the demand of electrical and heating loads for the improvement in overall system performance. An overall performance analysis should be carried out considering daylighting factor and potential implication of different photovoltaic technology in building with different orientation such as 
Table 8

Gain factor and loss coefficient of Hottel-Whiller Bliss equation for without and with surface water flow.

\begin{tabular}{|c|c|c|c|c|c|c|}
\hline \multirow[t]{2}{*}{ S. No } & \multirow[t]{2}{*}{ Cases } & \multirow[t]{2}{*}{ Modules } & \multicolumn{2}{|c|}{ Gain factor (fraction) } & \multicolumn{2}{|c|}{ Loss coefficient (fraction) } \\
\hline & & & Thermal & Electrical & Thermal & Electrical \\
\hline 1 & Without water flow & $\mathrm{m}-\mathrm{Si}$ & 0.15 & 0.13 & 1.98 & 0.51 \\
\hline 2 & & $\mathrm{p}-\mathrm{Si}$ & 0.15 & 0.12 & 1.88 & 0.41 \\
\hline 3 & & $\mathrm{a}-\mathrm{Si}$ & 0.15 & 0.06 & 1.60 & 0.23 \\
\hline 4 & & CdTe & 0.07 & 0.16 & 0.16 & 1.67 \\
\hline 5 & & CIGS & 0.16 & 0.86 & 1.34 & 0.29 \\
\hline 6 & With water flow & $\mathrm{m}-\mathrm{Si}$ & 0.10 & 0.13 & 11.82 & 1.05 \\
\hline 7 & & $\mathrm{p}-\mathrm{Si}$ & 0.08 & 0.11 & 11.63 & 0.89 \\
\hline 8 & & $\mathrm{a}-\mathrm{Si}$ & 0.04 & 0.06 & 07.62 & 0.11 \\
\hline 9 & & CdTe & 0.08 & 0.07 & 13.61 & 0.33 \\
\hline 10 & & CIGS & 0.09 & 0.08 & 11.17 & 0.60 \\
\hline
\end{tabular}

multifunctional glazing, transparent and semi-transparent external façade.

The experimental validation of analytical model lead to the conclusion that it can used in the predesigning the optimal system as per the requirements of overall loads and, what is also very important, to diagnosis a problem in the existing system if significant deviation is detected between observed and simulated values.

\section{Acknowledgement}

One of the authors (V.T.) is thankful to Ministry of New Renewable Energy (MNRE), New Delhi, India for providing financial assistance to pursue the research work.

\section{Appendix A}

The design parameters used to express the relations are shown in Tables 4 and 5. For m-Si and p-Si, $\alpha_{\tau} \neq 0, \beta_{c} \neq 1$ thus, $\alpha_{e}$ and $\alpha \tau_{e}$ refer for simplification of the Eqs. (1) \& (9), the term

$\alpha_{e}=\tau_{g}\left[\alpha_{c} \beta_{c}+\alpha_{\tau}\left(1-\beta_{c}\right)\right]$

$\alpha \tau_{e}=\alpha_{e}\left(1-R_{e}\right)-\eta_{m 0}\left(1+\beta_{o} T_{0}\right)$

$\alpha_{\tau}=0 \beta_{c}=1$, for a-Si, CdTe and CIGS therefore $\alpha_{e}$ and $\alpha \tau_{e}$ indicate to

$\alpha_{e}=\tau_{g} \alpha_{c} \beta_{c}$

$\alpha \tau_{e}=\alpha_{e}\left(1-R_{e}\right)-\eta_{m o}\left(1+\beta_{o} T_{0}\right)$

all other photovoltaic modules have a $\sum \frac{l}{k}$ value, except CIGS module, $\sum \frac{l}{k}=\left[\frac{l_{\mathrm{Gi}}}{k_{G i}}+\frac{l_{\text {arc }}}{k_{\text {arc }}}+\frac{l_{P V}}{k_{P V}}+\frac{l_{e c}}{k_{e c}}+\frac{l_{r m}}{k_{r m}}+\frac{l_{b}}{k_{b}}\right]$ for CIGS

$\sum \frac{l}{k}=\left[\frac{l_{\mathrm{Gi}}}{k_{G i}}+\frac{l_{a r c}}{k_{a r c}}+\frac{l_{P V}}{k_{P V}}+\frac{l_{e c}}{k_{e c}}+\frac{l_{r}}{k_{r}}\right]$

The refers term for test cell used in equations 6 and 16 is indicated as,

$U_{t} A_{t}=\left[\frac{1}{h i}+\frac{l_{i}}{k_{i}}+\frac{l_{w}}{k_{w}}+\frac{1}{h_{o}}\right]^{-1} \times A_{t}$

The simplification refers to heat transfer coefficient $h_{t w}$ from module to ambient used in Eq. (11). The expression for radiative heat transfer coefficient, $\mathrm{h}_{\mathrm{rw}}$ convective heat transfer coefficient, $\mathrm{h}_{\mathrm{cw}}$ and evaporative heat transfer coefficient, $\mathrm{h}_{\mathrm{ew}}$ is taken from Tiwari et al. [2,28] and Gaur and Tiwari [25]

$h_{t w}=h_{r w}+h_{c w}+h_{e w}$

$h_{r w}=\varepsilon \sigma\left\{\frac{\left(T_{w}+273\right)^{4}-\left(T_{a}+273\right)^{4}}{\left(T_{w}-T_{a}\right)}\right\}$, where $\varepsilon=0.9$ and $\sigma=5.67 \times 10^{-8} \mathrm{~W} / \mathrm{m}^{2} \mathrm{~K}^{4}$,

$h_{c w}=0.884\left\{\left(T_{w}-T_{a}\right)+\frac{\left(P_{w}-\gamma P_{a}\right) \times\left(T_{w}+273\right)}{\left(2.689 \times 10^{5}-P_{w}\right)}\right\}^{1 / 3}, \quad[25,28]$

$P(T)=\exp \left(25.317-\frac{5144}{T+273}\right)$

$h_{e w}=0.016 \times h_{c w}\left[\frac{P_{w}-\gamma P_{a}}{T_{w}-T_{a}}\right]$

$[25,28]$

$\alpha_{c}, \alpha_{\tau}, \beta_{c} \eta_{m o}$, and $\tau_{g}$ are obtained from generous work [2,25,27,28]. 


\section{References}

[1] Tomar V, Tiwari GN. Techno-economic evaluation of grid connected PV system for households with feed in tariff and time of day tariff regulation in New Delhi - a sustainable approach. Renew Sustain Energy Rev 2017;70:822-35.

[2] Tiwari GN, Mishra RK, Solanki SC. Photovoltaic modules and their applications: a review on thermal modeling. Appl Energy 2011;88:2287-304.

[3] Mondol JD, Yigzaw G, Yohanis YG, Norton B. Comparison of measured and predicted long term performance of grid a connected photovoltaic system. Energy Convers Manage 2007;48(4):1065-80.

[4] Skoplaki E, Palyvos JA. On the temperature dependence of photovoltaic module electrical performance: a review of efficiency/power correlation. Sol Energy 2009;83:614-24.

[5] Norton B, Eames PC, Mallick TC, Huang MJ, McCormack SJ, Mondol JD, et al. Enhancing the performance of building integrated photovoltaic. Sol Energy 2011;85(8):1629-64.

[6] Kern Jr EC, Russell MC. Combined photovoltaic and thermal hybrid collector systems. In: Proceedings of the 13th IEEE photovoltaic specialists. Washington, DC, USA; 1978. p. 1153-7.

[7] Abu-Bakar SH, Muhammad-Sukki F, Freier D, Ramirez-Iniguez R, Mallick TK, Munir AB. Performance analysis of a novel rotationally asymmetrical compound parabolic concentrator. Appl Energy 2015;154:221-31.

[8] Tian Y, Zhao CY. A review of solar collectors and thermal energy storage in solar thermal applications. Appl Energy 2013;104:538-53.

[9] Tripanagnostopoulos Y. Hybrid photovoltaic/thermal systems. Sol Energy 2002;72:217-34

[10] Soteris K. The potential of solar industrial process heat applications. Appl Energy 2003;76(4):337-61.

[11] Gholampour M, Ameri M. Energy and exergy analyses of photovoltaic/thermal flat transpired collectors: experimental and theoretical study. Appl Energy 2016;164:837-56.

[12] Sarhaddi F, Farahat S, Ajam H, Behzadmehr A, Mahdavi Adeli M. An improved thermal and electrical model for a solar photovoltaic thermal (PV/T) air collector. Appl Energy 2010;87:2328-39.

[13] Vats K, Tiwari GN. Energy and exergy analysis of a building integrated semitransparent photovoltaic thermal (BiSPVT) system. Appl Energy 2012;96:409-16.

[14] Vats K, Tomar V, Tiwari GN. Effect of packing factor on the performance of a building integrated semitransparent photovoltaic thermal (BiSPVT) system with air duct. Energy Build 2012;53:159-65.

[15] Agrawal B, Tiwari GN. Optimizing the energy and exergy of building integrated photovoltaic thermal (BiPVT) systems under cold climatic conditions. Appl Energy 2010;87:417-26.

[16] Chow TT, Pei G, Fong KF, Lin Z, Chan ALS, Ji J. Energy and exergy analysis of photovoltaic-thermal collector with and without glass cover. Appl Energy 2009;86:310-6.

[17] Chow TT. A review on photovoltaic/thermal hybrid solar technology review article. Appl Energy 2010;87(2):365-79.

[18] He W, Chow TT, Lu J, Pei G, Chan L. Hybrid photovoltaic and thermal solar collector designed for natural circulation of water. Appl Energy 2006;83:199-210.

[19] Amrizal N, Chemisana D, Rosell JI. Hybrid photovoltaic-thermal solar collectors dynamic modelling. Appl Energy 2013;101:797-807.

[20] Abdolzadeh M, Ameri M. Improving the effectiveness of a photovoltaic water pumping system by spraying water over the front of photovoltaic cells. J Renew Energy 2009;34:91-6.

[21] Dorobantu L, Popescu MO, Popescu CL, Crăciunescu A. Experimental assessments of PV panels front water cooling strategy. In: International conference on renewable energies and power quality (ICREPQ'13) Bilbao (Spain). 20-22th March, 2013; ISSN 2172-038 X, No.11.

[22] Kordzadeh A. The effects of nominal power of array and system head on the operation of photovoltaic water pumping set with array surface covered by a film of water. J Renew Energy 2010;35:1098-102.

[23] Krauter S, Hanitsch R, Campbell P, Wenham SR. Optical modeling, simulation and improvement of PV module encapsulation. In: Proceedings of the 12th European photovoltaic solar energy conference and exhibition, vol. 2. Amsterdam; 1994 April 11-15. p. 1198-201.

[24] Krauter S. Increased electrical yield via water flow over the front of photovoltaic panels. Solar Energy Mater Solar Cells 2004;82:131-7.

[25] Gaur A, Tiwari GN. Performance of a-Si thin film PV modules with and without water flow: an experimental validation. Appl Energy 2014;128. 184-19.

[26] Raghuraman P. Analytical predictions of liquid and air photovoltaic/thermal, flatplate collector performance. Solar Energy Eng 1981;103:291-8.

[27] Dubey S, Sandhu GS, Tiwari GN. Analytical expression for electrical efficiency of PVT hybrid air collector. Appl Energy 2009;86:697-705.

[28] Tiwari GN. Solar energy: fundamentals, design, modeling and applications. Narosa Publishing House; 2004.
[29] Geotzberger A, Hoffman VU. Photovoltaic solar energy generation. Berlin Heidelberg New York: Springer; 2005. p. 235.

[30] Ishii T, Otani K, Takashima T, Ikeda K. Change in I-V characteristics of thin-film photovoltaic (PV) modules induced by light soaking and thermal annealing effects. Progr Photovoltaic: Res Appl 2015;22(9):949-57.

[31] Wilhelm D, Lam KH, Close J. Efficiency and degradation of a copper indium diselenide photovoltaic module and yearly output at a sunny site in Jordan. Appl Energy 2006;83:1339-50.

[32] Wronski CR, Carlson DE. Amorphous silicon solar cells. In: Archer MD, Hill R, editors. Clean electricity from photovoltaic. Imperial College Press; 2001. p. 199-236

[33] Wu X, Keane JC, Dhere RG, DeHart C, Duda A, Gessert TA, et al. 16.5\%-efficient CdS/CdTe polycrystalline thin-film solar cell. In: 17th European photovoltaic solar energy conference Munich, Germany; 2001, p. 995-1000.

[34] Yamawaki T, Mizukami S, Masui T, Takahashi H. Experimental investigation on generated power of amorphous PV module for roof azimuth. Solar Energy Mater Solar Cells 2001;67:369-77.

[35] Zhao J, Wang A, Altermatt P, Green MA. Twenty-four percent efficient silicon solar cells with double layer antireflection coatings and reduced resistance loss. Appl Phys Lett 1995;66(26):3628-36.

[36] Soulayman S, Hammoud M. Optimum tilt angle of solar collectors for building applications in mid-latitude zone. Energy Convers Manage 2016;124:20-8.

[37] Ahmad MJ, Tiwari GN. Optimization of tilt angle for solar collector to receive maximum radiation. Open Renew Energy J 2009;2:19-24.

[38] Altarawneh IS, Rawadieh SI, Tarawneh MS, Alrowwad SM, Rimawi F. Optimal tilt angle trajectory for maximizing solar energy potential in Ma'an area in Jordan. J Renew Sustain Energy 2016;8:033701.

[39] Makrides G, Zinsser B, Georghiou GE, Schubert M, Werner JH. Temperature behaviour of different photovoltaic systems installed in Cyprus and Germany. Sol Energy Mater Sol Cells 2009;93:1095-9.

[40] Virtuani A, Mullejans H, Dunlop ED. Comparison of indoor and outdoor performance measurements of recent commercially available solar modules. Progr Photovoltaic: Res Appl 2011;19:11-20.

[41] Fuentes M, Nofuentes G, Aguilera J, Talavera DL, Castro M. Application and validation of algebraic methods to predict the behaviour of crystalline silicon PV modules in Mediterranean climates. Sol Energy 2007;81:1396-408.

[42] Müllejans H, Zaaiman W, Galleano R. Analysis and mitigation of measurement uncertainty in the traceability chain for the calibration of photovoltaic devices. Meas Sci Technol 2009;20:1-6.

[43] Akpinar EK. Drying of mint leaves in a solar dryer and under open sun: modelling, performance analyses. Energy Convers Manage 2010;51:2407-18.

[44] ISO. Guide to the Expression of Uncertainty in Measurement, first edition, ISO, Geneve; 1995. p. 1-27.

[45] Dirnberger D, Bartke J, Steinhüser A, Kiefer K, Neuberger F. Uncertainty of Field IV-Curve Measurements in Large Scale PV-Systems“, 25th EU PVSEC, Valencia; 2010. doi: 10.4229/25thEUPVSEC2010-4BV.1.62.

[46] Evans DL. Simplified method for predicting PV array output. Sol Energy 1981;27:555-60.

[47] Fujisawa T, Tani T. Annual exergy evaluation on photovoltaic-thermal hybrid collector. Solar Energy Mater Solar Cells 1997;47:135-48.

[48] Chapra SC, Canale RP. Numerical methods for engineers. US: McGraw-Hill Inc.; 1988.

[49] International Electrotechnical Commission, Procedures for temperature and irradiance corrections to measured I-V characteristics, IEC 60891, 2nd ed. IEC, Geneva, Switzerland 2009-12.

[50] Marion B. A method for modeling the current-voltage curve of a PV module for outdoor conditions. Progr Photovoltaic: Res Appl 2002;10:205-14.

[51] Rajput P, Tiwari GN, Sastry OS, Bora B, Sharma V. Degradation of monocrystalline photovoltaic modules after 22 years of outdoor exposure in the composite climate of India. Sol Energy 2016;135:786-95.

[52] Jordan DC, Kurtz SR. NREL/JA-5200-51664 June 2012.

[53] Liu BYH, Jordan RC. The interrelationship and characteristics distribution of direct and diffuse and total solar radiation. Sol Energy 1960;4(1):1-19.

[54] Ishii T, Otani K, Takashima T, Kawai S. Estimation of the maximum power temperature coefficients of PV modules at different time scales. Solar Energy Mater Solar Cells 2011;95:386-9.

[55] Mishra RK, Tiwari GN. Energy and exergy analysis of hybrid photovoltaic thermal water collector for constant collection temperature mode. Sol Energy 2013;90:58-67.

[56] Florschuetz LW. Extension of the Hottel-Whillier model to the analysis of combined photovoltaic/thermal flat plate collectors. Sol Energy 1979;22:361-6.

[57] Hottel HC, Whillier A. Evaluation of flate plate collector performance. Trans of the conference on the use of solar energy, vol. 2. University of Arizona Press; 1958. p. 74 . 